\title{
Topographic response to Neogene variations in slab geometry, climate and drainage reorganization in the Northern Andes of Colombia
}

Nicolás Pérez-Consuegra ${ }^{1 *}$, Richard F. Ott ${ }^{2}$, Gregory D. Hoke ${ }^{1}$, Jorge P. Galve ${ }^{3}$, Vicente Pérez-Peña ${ }^{3}$

1. Department of Earth and Environmental Sciences, Syracuse University. Syracuse, USA

2. German Centre for Geoscience Research, Potsdam, Germany

3. Departamento de Geodinámica, Universidad de Granada. Granada, Spain

*corresponding author. Email: nperezco@syr.edu

This is a non-peer reviewed preprint and has been submitted to Global Planetary Change (Special Issue).

Keywords: River capture, surface uplift, knickpoint migration, tropics, biodiversity 


\begin{abstract}
The tropical Northern Andes of Colombia are one the world's most biodiverse places, offering an ideal location for unraveling the linkages between the geodynamic forces that build topography and the evolution of the biota that inhabit it. In this study, we utilize geomorphic analysis to characterize the topography of the Western and Central Cordilleras of the Northern Andes. We supplement our topographic analysis with erosion rate estimates based on gauged suspended sediment loads and river incision rates from volcanic sequences. In the northern Central Cordillera, an elevated low-relief surface $(2,500 \mathrm{~m}$ in elevation, $\sim 40 \mathrm{x} 110 \mathrm{~km}$ in size) with quasi-uniform lithology and surrounded by knickpoints, indicates a recent increase in rock and surface uplift rate. Whereas the southern segment of the Central Cordillera shows substantially higher local relief and mostly well graded river profiles consistent with longer term uplift-rate stability. We also identify several areas of major drainage reorganization, including captures and divide migrations that are supported by our erosion and incision rate estimates. These changes in the topography coincide with the proposed location of a slab tear and flat slab subduction under the northern Central Cordillera, as well as with a major transition in the channel slope of the Cauca River. We identify slab flattening as the most likely cause of strong and recent uplift in the Northern Andes leading to $\sim 2 \mathrm{~km}$ of surface uplift since 8-4 Ma. Large scale drainage reorganization of major rivers is probably mainly driven by changes in upper plate deformation in relation to development of the flat slab subduction geometry; however, other factors such as climate and emplacement of volcanic rocks likely play secondary roles in this process. Several isolated biologic observations above the area of slab flattening suggest that surface uplift isolated former lowland species on the high elevation plateaus, and drainage reorganization may have influenced the distribution of aquatic species.
\end{abstract}

\title{
1. Introduction
}

Since Alexander von Humboldt's work on the Chimborazo volcano, the Northern Andes of South America have been noted as one of Earth's most biodiverse regions (Rahbek et al., 2019). Many studies have shown that topography and its evolution through time are important predictors of modern-day biodiversity globally, and especially within the Northern Andes (Antonelli and Sanmartín, 2011; Badgley et al., 2017; Antonelli et al., 2018). Therefore, a clear understanding of the timing and spatial patterns of topographic growth is necessary to discern the generation of the observed modern biodiversity patterns in the Andes (Hoorn et al., 2010; Luebert and Weigend, 2014; Baker et al., 2014), but is also critical to identifying the tectonic, geodynamic and climatic processes that generate topography (Garzione et al., 2017; Horton, 2018; Schildgen and Hoke, 2018). The Northern Andes of Colombia are a region of complex topography above the Nazca subduction zone, with three roughly north-south striking parallel mountain 
chains separated by intermontane basins. The regional topography is overall controlled by subduction processes, yet we know little about the topographic growth especially of the Western and Central Cordillera. A change in subduction geometry from steep to shallow beginning around 6-8 Ma has been proposed, which is expected to have a significant effect on topography (e.g., Eakin et al., 2014) and by extension, an imprint in modern biodiversity. However, the topographic evolution of the Western and Central Cordillera remains elusive, as do the contributions of different drivers of topographic change such as subduction geometry, drainage reorganization and climate.

The tectonic evolution of the Central and Western Cordilleras of the Northern Andes begins in the Late Cretaceous based on thermochronology, a method that records the cooling of rocks as they are advected towards the surface via the removal of overlying rocks, termed exhumation (Villagómez and Spikings, 2013). In general, thermochronologic data from the Central Cordillera point towards high rates of exhumation in the Late Cretaceous to Paleogene between $\sim 50-70 \mathrm{Ma}$, related to the accretion of oceanic terranes (Villagómez and Spikings, 2013). The Western Cordillera shows a pulse of exhumation at $40 \mathrm{Ma}$ followed by a decrease in rates (Villagómez and Spikings, 2013). The Neogene topographic evolution of the Western and Central Cordilleras of the Northern Andes remains poorly understood (e.g., Mora et al., 2020). During the Middle Miocene (ca. 12-15 Ma) the Panama Block collided with northern South America (Farris et al., 2011; Montes et al., 2012, 2015) and at ca. 6-8 Ma the Nazca slab tore, and flat slab subduction initiated north of $\sim 5^{\circ} \mathrm{N}$ (Vargas and Mann, 2013; Fig. 1A, Chiarabba et al., 2016; Wagner et al., 2017). Inverse thermal history models from apatite fission track data in the Western and Central Cordilleras show higher rates of exhumation in the past 40 Ma south of the slab tear (Villagómez and Spikings, 2013). Apatite (U-Th)/He (AHe) ages of the Central Cordillera, which record exhumation from $\sim 2-3 \mathrm{~km}$ in the crust, are younger south of the slab tear, indicating higher exhumation compared to the north.

The cause of the differences in thermochronological ages, and the general effects of the transition from normal to flat slab on the Western and Central Cordilleras' topography remain elusive. The onset of flat slab subduction is expected to generate more coupling between the subducting and overriding plate and result in increased crustal shortening in the upper plate (Jordan et al., 1983; Gutscher et al., 2000; Espurt et al., 2008; Horton, 2018). The increased rates of shortening and the isostatic adjustment due to slab flattening would be expected to generate an increase of rock uplift above the zone of flat slab subduction (Espurt et al., 2008; e.g., Eakin et al., 2014), yet thermochronological data record more and faster exhumation in the southern steeper slab segment (Villagómez and Spikings, 2013). The rate dependent integration time of the employed thermochronometers may be too long to capture a recent increase in uplift rates in the north in response to slab flattening. Such changes in subduction dynamics and tectonic uplift rates may also induce drainage reorganization. Yet, there is no data on past and present rates of modern drainage reorganization 
within the Central and Western Cordillera. The uplift of the Northern Andes has also created a west to east rainfall gradient across the Western Cordillera, with focused orographic precipitation on the western flank (Fig. 1) that may have left an imprint on topography.

In this paper, we use geomorphic tools to characterize the topography of the Western and Central Cordilleras of the Northern Andes (Colombia), identify areas and mechanisms of drainage reorganization, and discuss the roles of subduction geometry and slab flattening, volcanism and climate gradients in the topographic evolution of the region. Our analysis combines simple topographic observations through swath profiles and detailed analyses of the river network. We employ the analysis of river long profiles to map knickpoints (kinks in river profiles) that can be related to temporal changes in tectonic uplift rates (e.g., Wobus et al., 2006), and river steepness to elucidate spatial patterns of uplift and erosion rates. We also investigate metrics that indicate drainage reorganization, e.g., the $\chi$-index to map the stability of drainage basins (Willett et al., 2014; Forte and Whipple, 2018; Scherler and Schwanghart, 2020). We integrate our topographic observations with geological data, climatic data and erosion rate estimates based on gauged suspended sediment loads. We identify a signal of recent increase in uplift rate in the northern Central Cordillera and identify slab flattening as the most likely cause. Large scale drainage reorganization of major rivers is mainly driven by the same changes in subduction geometry, however other factors such as climate and emplacement of volcanic rocks likely play secondary roles in this process. Several isolated biologic observations above the area of slab flattening suggest that the topographic changes may have isolated former lowland species on high elevation plateaus, and drainage reorganization may have driven speciation and extinction of aquatic species. 

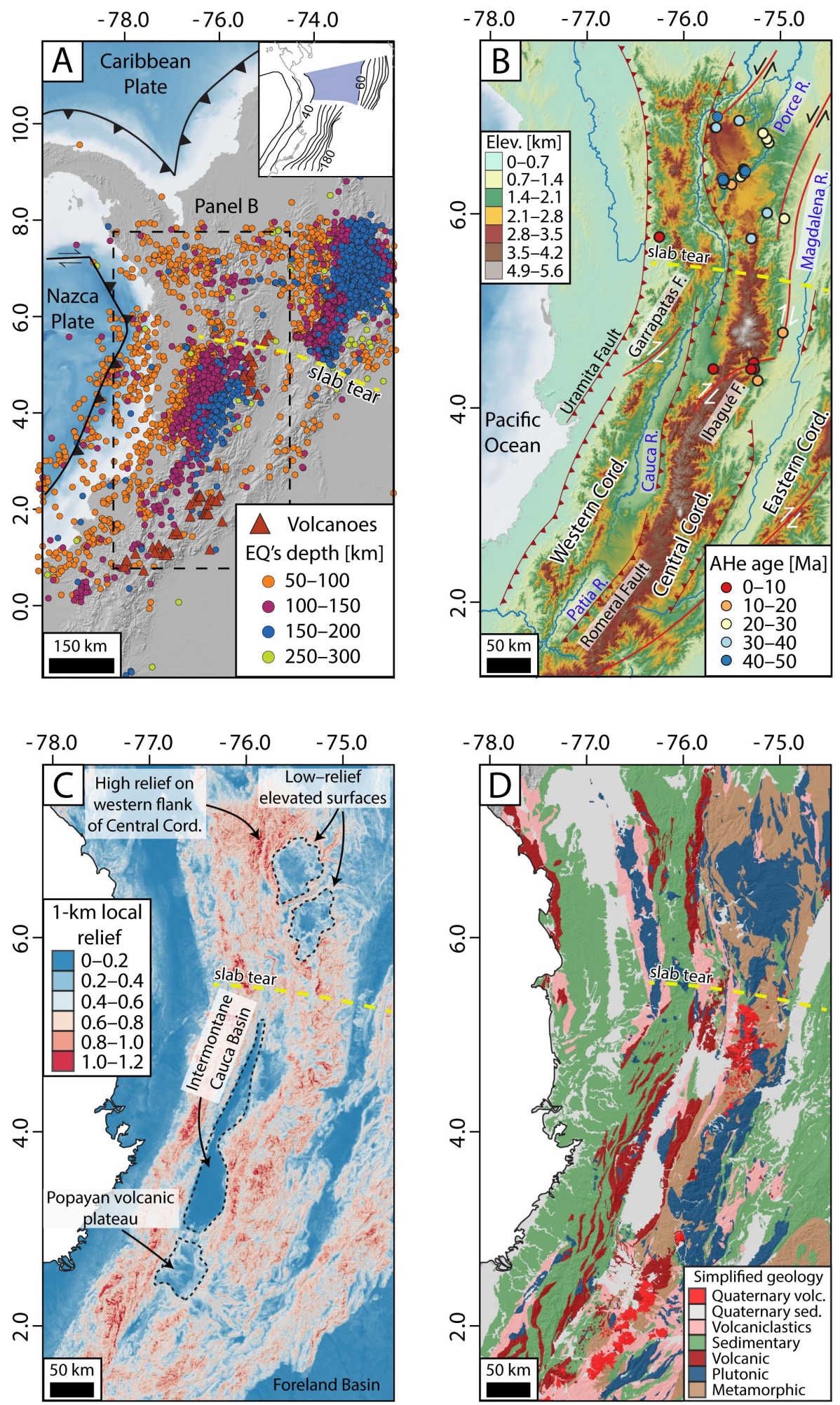

Fig. 1. Study area overview. A. Shaded relief showing the spatial distribution of volcanoes and earthquake hypocenters deeper than $50 \mathrm{~km}$. Inset: slab depth contours from Wagner et al. 2017, with blue shading highlighting the flat slab. B. Topography of the Western and Central Cordilleras and main geological structures (modified from Veloza et al., 2012), as well as compiled apatite (U-Th)/He (AHe) thermochronology ages (Villagomez and Spikings, 2013; Restrepo-Moreno et al., 2009). C. Local relief calculated with a 1-km radius. D. Simplified lithologic map of the Northern Andes (modified from Gomez et al., 2015). 


\section{Geological Setting}

\subsection{Regional tectonic setting}

The northwestern margin of South America is a convergent plate boundary with active subduction, volcanism and seismic activity. The Northern Andes are bounded to the west by the Nazca subduction trench and the Panama Block, by the South Caribbean Deformed Belt to the north, and the East Andean Fault System to the east (e.g., Pennington, 1981). The Nazca Plate subducts below South America at a rate of $\sim 5 \mathrm{~cm} / \mathrm{yr}$ (e.g., Trenkamp et al., 2002). In the Middle Miocene (ca. 12-15 Ma) the Panama Block collided with northwest South America producing rock uplift and closure of the Central American Seaway (Farris et al., 2011; Montes et al., 2012, 2015; León et al., 2018). Based on seismic evidence it has been proposed that there is a slab tear, in the subducting Nazca plate at $\sim 5^{\circ} \mathrm{N}$ that separates a flat slab segment to the north from a normal segment dipping at $\sim 45^{\circ}$ to the south (Gutscher et al., 2000; Vargas and Mann, 2013; e.g., Chiarabba et al., 2016). The spatial and temporal changes in the distribution of volcanism from the Miocene to the present have been used to reconstruct the evolution of the slab geometry and the onset of flat slab subduction at $\sim 6-8 \mathrm{Ma}$ (Wagner et al., 2017).

\subsection{Geology of the Western and Central Cordillera}

The Northern Andes comprise three roughly north striking mountain ranges - the Western, Central and Eastern Cordilleras separated by the Cauca and Magdalena intermontane basins (Fig. 1B). The Central Cordillera is composed of pre-Mesozoic, low- to high-grade metamorphic basement of mixed continental and oceanic origin that is intruded by numerous Mesozoic-Cenozoic plutons of the Andean magmatic arc (Aspden and McCourt, 1986; Aspden et al., 1987; Cediel et al., 2005). The Western Cordillera is mainly composed of Cretaceous volcanic and sedimentary rocks of oceanic affinity that were accreted to the continental margin of the Central Cordillera during the Paleogene along the suture and major active fault known as the Cauca-Romeral Fault (e.g., Kerr et al., 1997; Kerr and Tarney, 2005).

The Cauca-Romeral Fault marks the eastern boundary of the Cauca Basin and western boundary of the Central Cordillera. Regionally, the Cauca-Romeral Fault consists of a west-vergent thrust fault system which thrusts metamorphic basement of the Central Cordillera and Cretaceous ophiolitic basement over the Cenozoic deposits of the Cauca Basin (e.g., Alfonso et al., 1994). However, it is also a major strike slip fault and the kinematics of the fault change along its course (Paris et al., 2000; Veloza et al., 2012). The basement of the Cauca Basin is composed of the same Cretaceous ophiolitic rocks of the Western Cordillera, unconformably overlain by up to $\sim 4 \mathrm{~km}$ of Paleocene to middle Miocene marine and continental 
sedimentary rocks (e.g., Alfonso et al., 1994), which in turn are unconformably overlain by late Miocene to Holocene alluvial and lacustrine sediments. The late Miocene to Holocene sedimentary rocks are locally deformed with both syn- and post-depositional faulting related to the transpressional regime of this part of the Colombian Andes (Neuwerth et al., 2006; Suter et al., 2008). The Patía intermontane basin (Fig. 1) also consists of Cretaceous ophiolitic basement unconformably overlain by deformed Paleocene-Miocene rocks (Gallego-Ríos et al., 2020), followed by an unconformity covered by flat lying Pliocene to Quaternary volcanic and volcaniclastic rocks (Murcia and Cepeda, 1991a; Echeverri et al., 2015; Gallego-Ríos et al., 2020).

The Western Cordillera is bounded to the west by the Uramita Fault Zone, a major suture zone with a transpressional regime (e.g., Duque-Caro, 1990; Trenkamp et al., 2002; León et al., 2018). In its southern segment, the eastern flank of the Central Cordillera is bounded by the Plata-Chusma Fault (reverse). The northern Central Cordillera forms an east-dipping basement that is buried beneath the Middle Magdalena Valley Basin (Gómez et al., 2003, 2005). The slip rates of the east-bounding fault of the northern Central Cordillera are likely lower compared to the slip rates on the west bounding Romeral Fault zone (e.g., Gomez et al., 2003).

\subsection{Climate}

In the Western and Central Cordilleras of Colombia, moisture is transported from the Pacific Ocean by the low-level (i.e., low elevation) westerly winds of the Choco Jet and from the Atlantic Ocean by highlevel easterly (trade) winds. The western side of the Western Cordillera forms a strong orographic barrier where precipitation is focused, making it one of Earth's rainiest locations with precipitation rates of 8-13 m/yr (e.g., Poveda and Mesa, 2000). The eastern flank of the Western Cordillera and the intermontane valleys between the Western and Central Cordilleras only receive $\sim 2-3 \mathrm{~m} / \mathrm{yr}$ of precipitation.

\section{Methods}

\subsection{Topographic and river network analyses}

We analyzed the spatial variations in topography in the Western and Central Cordillera of the Northern Andes by calculating different geomorphic metrics using Topotoolbox (Schwanghart and Scherler, 2014) and the 90 m GLO-90 digital elevation model (DEM) from the European Space Agency (https://spacedata.copernicus.eu), together with Geographic Information Systems (GIS software) for graphical display. Topographic metrics calculated from the DEM include local relief, hillslope gradient and swath profiles. 
Local relief was calculated from the difference between the minimum and maximum elevations within a $0.5 \mathrm{~km}$ (Fig. 5,6) and 1-km (Fig. 1C) radius. Hillslope gradient was calculated as the rise over run change in elevation across cells of the DEM. Swath profiles are cross-sections of topography calculated by averaging data along a rectangle of prescribed width.

We analyze the river network of the Western and Central Cordillera, because rivers can record temporal and spatial tectonic and climatic signals (e.g., Wobus et al., 2006). Therefore, we calculated the normalized channel steepness index $\left(k_{s n}\right)$ (Whipple and Tucker, 1999), and $\chi$ (Perron and Royden, 2013) as well as river elevation versus $\chi$-profiles. The elevation of a river profile is commonly described by the stream power incision model (Howard, 1994):

(1) $\mathrm{dz} / \mathrm{dt}=\mathrm{U}-\mathrm{E}=\mathrm{U}-\mathrm{K}^{*} \mathrm{~A}^{\mathrm{m} *} \mathrm{~S}^{\mathrm{n}}$

where $\mathrm{U}$ is the rock uplift rate, E erosion rate, A drainage area, $\mathrm{S}$ the local channel slope, $\mathrm{m}$ and $\mathrm{n}$ empirical scaling factors, and $\mathrm{K}$ a dimensional coefficient that incorporates the effects of lithology, climate, incision process and hydrology (e.g., Whipple and Tucker, 1999). Rivers will tend to balance the amount of rock uplift by erosion to achieve a steady state profile over time $(\mathrm{dz} / \mathrm{dt}=0)$. In this case, the local steady state channel slope can be expressed as

(2) $\mathrm{S}=\mathrm{k}_{\mathrm{s}} * \mathrm{~A}^{-\theta}$

with (3) $\mathrm{k}_{\mathrm{s}}=(\mathrm{U} / \mathrm{K})^{1 / \mathrm{n}}$ and:

(4) $\theta=m / n$

where $\mathrm{k}_{\mathrm{s}}$ is the channel steepness corrected for drainage area (Flint, 1974). $\theta$ is the river profile concavity and often fixed to a reference value $\left(\theta_{\text {ref }}\right)$ to calculate the normalized channel steepness, which allows the comparison of rivers within a region (e.g., Wobus et al., 2006):

(5) $\mathrm{S}=k_{s n} * \mathrm{~A}^{-\theta r e f}$

$k_{s n}$ can now be used to infer differences in rock uplift rates of steady state rivers within regions of constant or similar K, e.g., regions of similar lithology and climate. The values of $k_{s n}$ and concavity can be estimated by logarithmic regression of channel slope and drainage area data. However, this analysis can be noisy and Perron and Royden (2013) introduced the $\chi$-integral method to make this analysis more robust. Assuming spatially invariant $U$ and $K$ equation (5) can be integrated to

(6) $\mathrm{z}(\mathrm{x})=\mathrm{z}\left(\mathrm{x}_{\mathrm{b}}\right) *\left(\mathrm{U} / \mathrm{KA}_{0}{ }^{\mathrm{m}}\right)^{1 / \mathrm{n} *} \chi$ 
(7) $\chi=$ integral from $\mathrm{xb}$ to $\mathrm{x}\left(\mathrm{A}_{0} / \mathrm{A}\right)^{\theta \mathrm{ref}}$

where $\mathrm{x}_{\mathrm{b}}$ is the base level for integration, $\mathrm{A}_{0}$ an arbitrary scaling area, and $\chi$ the horizontal transformation of the distance along the river. It is important to notice that the slope of $\chi$ versus elevation plots is equivalent to the channel steepness $k_{s n}$, if $\mathrm{A}_{0}$ is assumed to be 1 . Therefore, $\chi$-elevation plots are a simple way of assessing the steepness of a river and its potential variations along profile. Furthermore, differences of $\chi$-values across drainage divides can indicate differences in river steepness and basin geometry and therefore predict the migration of drainage divides (for more details see e.g., Willett et al., 2014).

We find our best-fit river channel concavity of the region with a Bayesian optimization algorithm. Steady state river profiles should exhibit a straight line in $\chi$-elevation plots (Royden and Perron, 2013). We clip DEMs of the Western and Central Cordillera to the fronts of the mountain ranges to avoid alluviated foreland rivers and use a TopoToolbox algorithm for the optimization. The algorithm selects random subsets of the river network and finds the concavity that best linearizes the $\chi$-elevation profiles of the region. We find a best fit of $\theta_{\text {ref }}=0.5$ both in the Western and Central Cordillera (Fig. S1) and use this value for all subsequent calculations of $k_{s n}$ and $\chi$.

Knickpoints are points or short segments in which streams change their channel steepness and they can be indicative of temporal changes in uplift rate (e.g., Wobus et al., 2006). To identify regions where uplift rates may have recently changed, in an objective manner, we use a knickpoint-search algorithm (Schwanghart and Scherler, 2014). The algorithm identifies (upward) convexities in river profiles, by measuring the offset between the actual river profile and a strictly concave projection. A knickpoint is identified if the difference between the actual and projected profile exceeds a tolerance value of $200 \mathrm{~m}$.

Within the stream power model, drainage area is commonly used as a proxy for river discharge (e.g., Wobus et al., 2006). However, in areas like the Western Cordillera, where strong gradients in rainfall occur, the assumption of a constant drainage area to discharge scaling may be violated. We therefore also use the CHELSA-derived mean annual precipitation (MAP) as a proxy for discharge and derive the precipitation corrected normalized channel steepness (Adams et al., 2020):

(8) $k_{s n} \mathrm{P}=\mathrm{Q}^{\theta \mathrm{ref} * \mathrm{~S}}$

where discharge $\mathrm{Q}$ is the product of drainage area and upstream MAP. We acknowledge that in this process we are ignoring evapotranspiration. 
We utilize DivideTools (Forte and Whipple, 2018) to calculate drainage divide stability metrics averaged upstream of a reference drainage area $\left(10^{7} \mathrm{~m}^{2}\right)$ for selected basins across major drainage divides. We employ across-divide differences in mean gradient, mean local relief and $\chi$.

\subsection{Climate data}

We use remotely sensed precipitation to explore how climate may influence topography. Mean annual precipitation (MAP) data are taken from the CHELSA database with $1 \mathrm{~km}$ resolution (Karger et al., 2017). We acknowledge that historical precipitation datasets are imperfect for comparison with geomorphic data, because these products characterize precipitation over the past few decades while the landscapes evolve on $10^{3}-10^{6}$ years timescales. Nevertheless, we use the historical climate data as a first order estimate.

\subsection{Erosion rates estimates}

We calculate erosion rates from mean-monthly suspended load data (e.g., Carretier et al., 2018) from three hydrological stations in the Cauca and Patía Catchments managed by the Instituto de Hidrología, Meteorología y Estudios Ambientales (IDEAM, Colombia). In the Cauca, stations are located at the northern termination of the Upper Cauca Valley (IDEAM Station 26207030; N 5.26 ${ }^{\circ}$ W -75.66 $)$ and downstream of the mouth of the Cauca Canyon (IDEAM Station 26247020; N 7.96 ${ }^{\circ}$, W $-75.18^{\circ}$ ), where the Cauca enters the plain of the Lower Magdalena Valley Basin. Another station is located at the outlet of the Upper Patía Valley (IDEAM Station 52017010; N 1.59, $\mathrm{W}-77.24^{\circ}$ ) at the eastern margin of the Western Cordillera. The datasets span 32-40 years. The data is provided as kTon/month that we converted to erosion rates by averaging all the monthly values and multiplying the averages by 12 to obtain a mean annual suspended sediment discharge (KTon/yr). Dividing this value by an estimated initial rock density of

$2,600 \pm 200\left(\mathrm{~kg} / \mathrm{m}^{3}\right)$ and by the catchment area $\left(\mathrm{m}^{2}\right)$ gives an estimate of the catchment mean erosion rate $(\mathrm{m} / \mathrm{Ma})$. We report the erosion rates with an uncertainty of $\pm 50 \%$ for the average monthly suspended load value and $\pm 200 \mathrm{~kg} / \mathrm{m}^{3}$ uncertainty of the density.

\section{Results}

\subsection{Topography north and south of the slab tear}

The E-W swath profiles across the Central Cordillera (Fig. 2A,B) show that north of the slab tear the topography forms a low-relief plateau about $40 \mathrm{~km}$ wide and at $\sim 2,500 \mathrm{~m}$ elevation, the Antioqueño Plateau (AP). Local relief on this plateau is $\sim 200 \mathrm{~m}$. At its eastern margin the AP transitions into a $\sim 70 \mathrm{~km}$ 
long east sloping surface of similarly low relief that is in parts dissected by up to $900 \mathrm{~m}$ deep river canyons, before transitioning into the Magdalena River Valley.
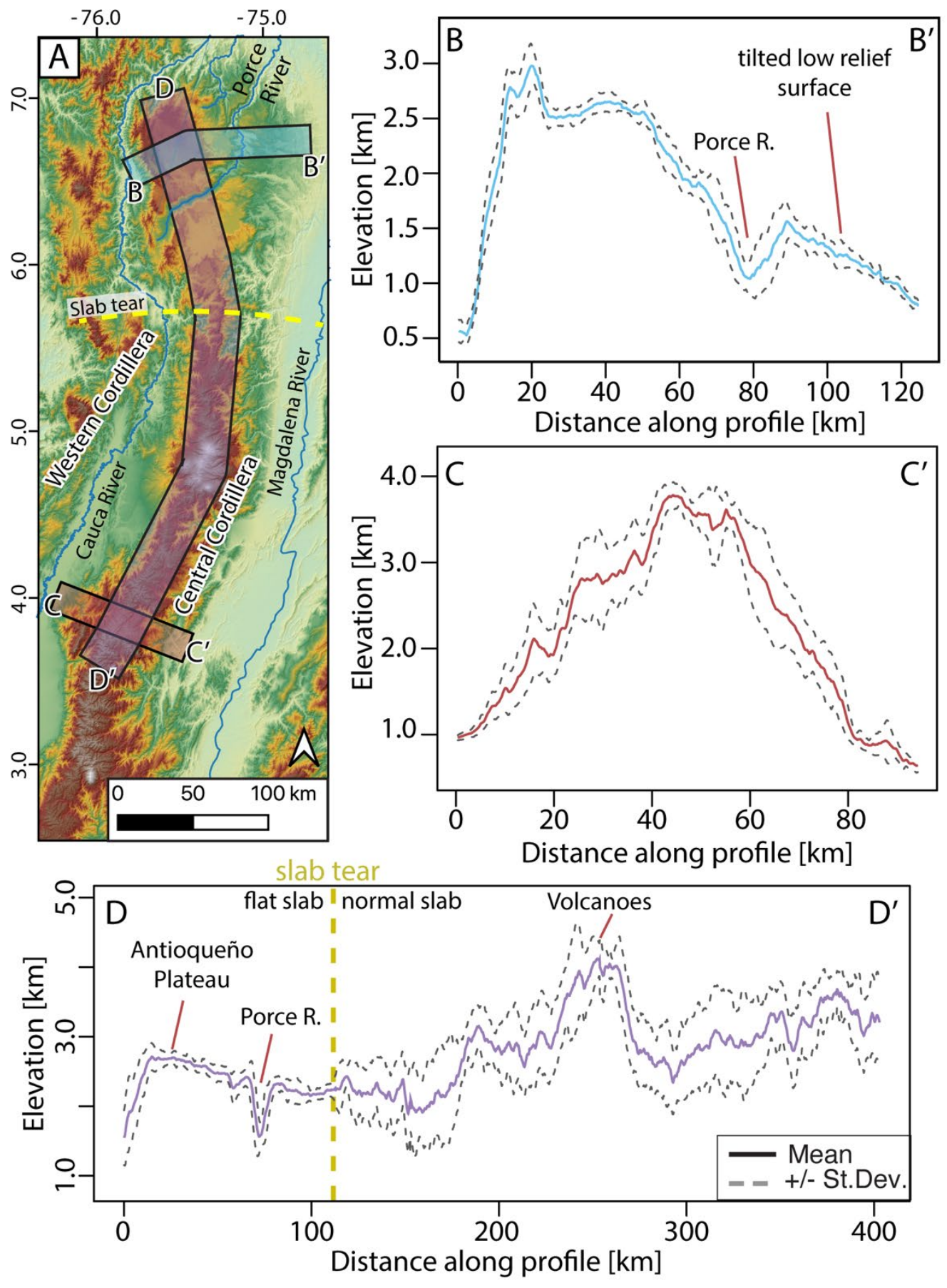

Fig. 2. Along strike variations in the topography of the Central Cordillera. A. Topography of the Central Cordillera with the location of the swath profiles $B-D$. 
South of the slab tear, the E-W swath profile across the Central Cordillera reveals a more symmetrical, pyramidal mountain range (Fig. 2C). Increased variance in topography indicates substantially higher local relief of $\sim 600 \mathrm{~m}$ compared to the northern Central Cordillera. The N-S swath profile along the crest of the Central Cordillera shows the same pattern, where north of the slab tear the landscape forms a low relief high elevation region in parts dissected by deep river valleys, and south of the slab tear relief increases substantially.

\subsection{River network analysis: $k_{s n}, \chi$ and river profiles}

The drainage network metrics also show differences north and south of the slab tear (Figure 3). North of the slab tear, channel steepness is low in the low-relief surfaces around the Antioqueño Plateau and higher along the margins of the Central Cordillera. To the south, channel steepness is generally high in the Central Cordillera and low in the intermontane Cauca Basin.
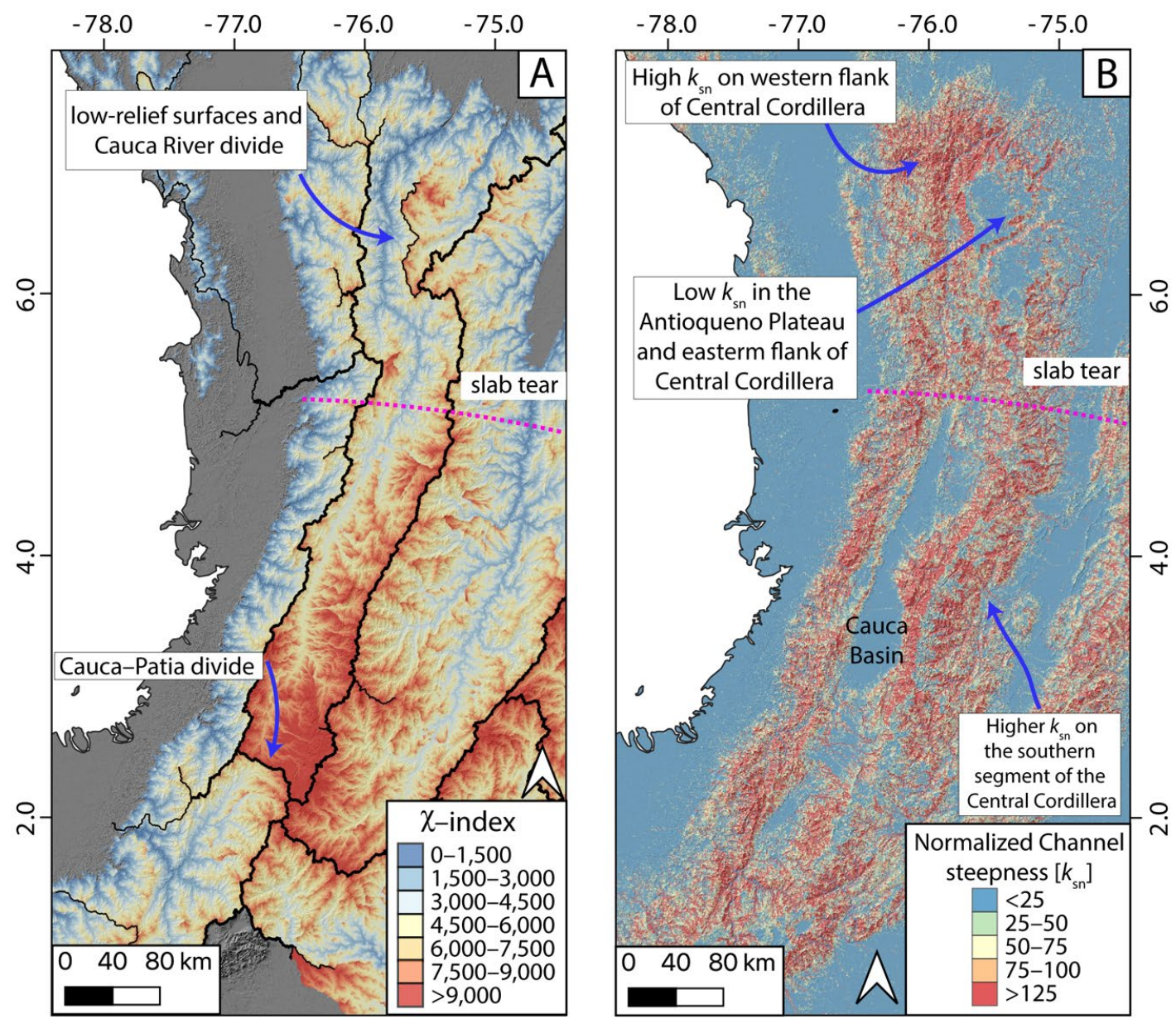

Fig. 3. River network metrics. A. $\chi$-map of the Western and Central Cordillera. B. Map of normalized channel steepness index $\left(k_{s n}\right)$. 
North of the slab tear, $\chi$ maps show contrasting $\chi$ values between the catchments draining large portions of the low-relief surfaces (high $\chi$ values) and the catchments draining the steep margins of the western flank of the Central Cordillera into the Cauca River (low $\chi$ values). This suggests that drainage divide migration is occurring and the steep catchments draining the western flank of the Central Cordillera are capturing area from the catchments draining the low-relief surfaces of the Antioqueño Plateau. Across divide $\chi$-values can be biased by differences in uplift rate, therefore we also compared other topographic metrics indicative of divide migration. The across divide differences in hillslope gradient and local relief document higher relief and gradient on the divide side with lower $\chi$ value (western flank of Central Cordillera) and are consistent with the divide motion predicted by the $\chi$-values (Figs. 3A and 4A). South of the slab tear, a large contrast in $\chi$ appears between the headwaters of the Cauca and Patía rivers (Figs. 3A and $4 \mathrm{~B})$. Values of $\chi$ are higher in the headwaters of the Cauca Basin. This pattern in $\chi$ suggests that drainage divide migration is occurring and the steep Patía Basin is capturing area from the upper segment of the Cauca River Basin. This is also reflected in the channel steepness values and hillslope gradient across the drainage divide of the upper Patía and Cauca river basins, with higher values in the Patía River Basin. Rivers draining the western flank of the Western Cordillera also have a marked difference in $\chi$ with respect to the rivers draining the eastern flank into the Cauca Basin. Rivers draining the western flank of the Western Cordillera drain directly to the Pacific, whereas rivers draining the eastern flank enter the sedimentary Cauca Basin at elevations of $\sim 900-1,000 \mathrm{~m}$, which serves as the baselevel for these rivers. Therefore, this contrast in $\chi$ is due to differences in baselevel and mostly disappears when a baselevel of $950 \mathrm{~m}$ is used for calculation (Fig. S2).

North of the slab tear, multiple knickpoints are located mostly at the margins of the low-relief surfaces in the northern Central Cordillera, where rivers leave the low-relief surfaces of the Antioqueño Plateau and form steep canyons (Fig. 5 A,B). Knickpoint elevations within a region are similar but decrease in elevation towards the east (Fig. 5B). The lithologies are mostly granite and gneiss and knickpoints do not correspond to bedrock transitions. River profiles in the northern Western Cordillera are mostly well graded and rarely exhibit knickpoints, though rivers draining the northernmost part of the Western Cordillera seem to have a higher concavity compared to the rest of the Northern Andes (Fig. 5C). 

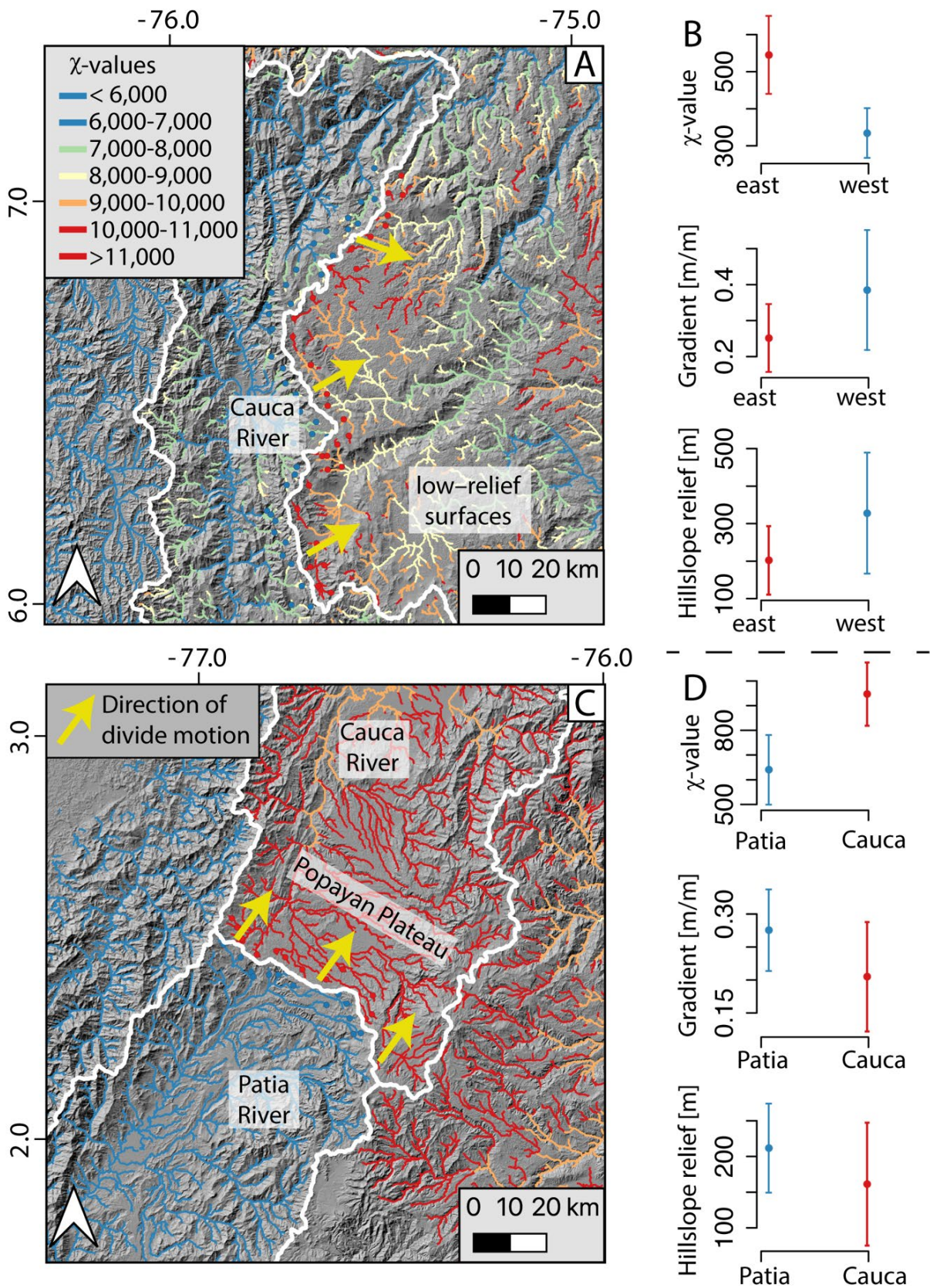

Fig. 4. Close up of prominent disequilibrium divides bordering the Cauca River basin. A. $\chi$-map of the northern Central and Western Cordilleras. B. Median and quartile values of channel head $\chi$, local relief (500m radius), and hillslope gradient for both sides of the divide in (A). Channel heads included in the calculation are highlighted by circles. The divide between the Cauca River and the low-relief surfaces of the Central Cordillera is predicted to migrate towards the east as indicated by the differences in $\chi$, hillslope gradient, and local relief. C. $\chi$-map of the southern Central and Western Cordillera and the drainage divide between the Cauca and Patía rivers. D. Same as (B) for the Cauca-Patia divide shown in (C). The topographic metrics predict divide migration towards the northeast. 

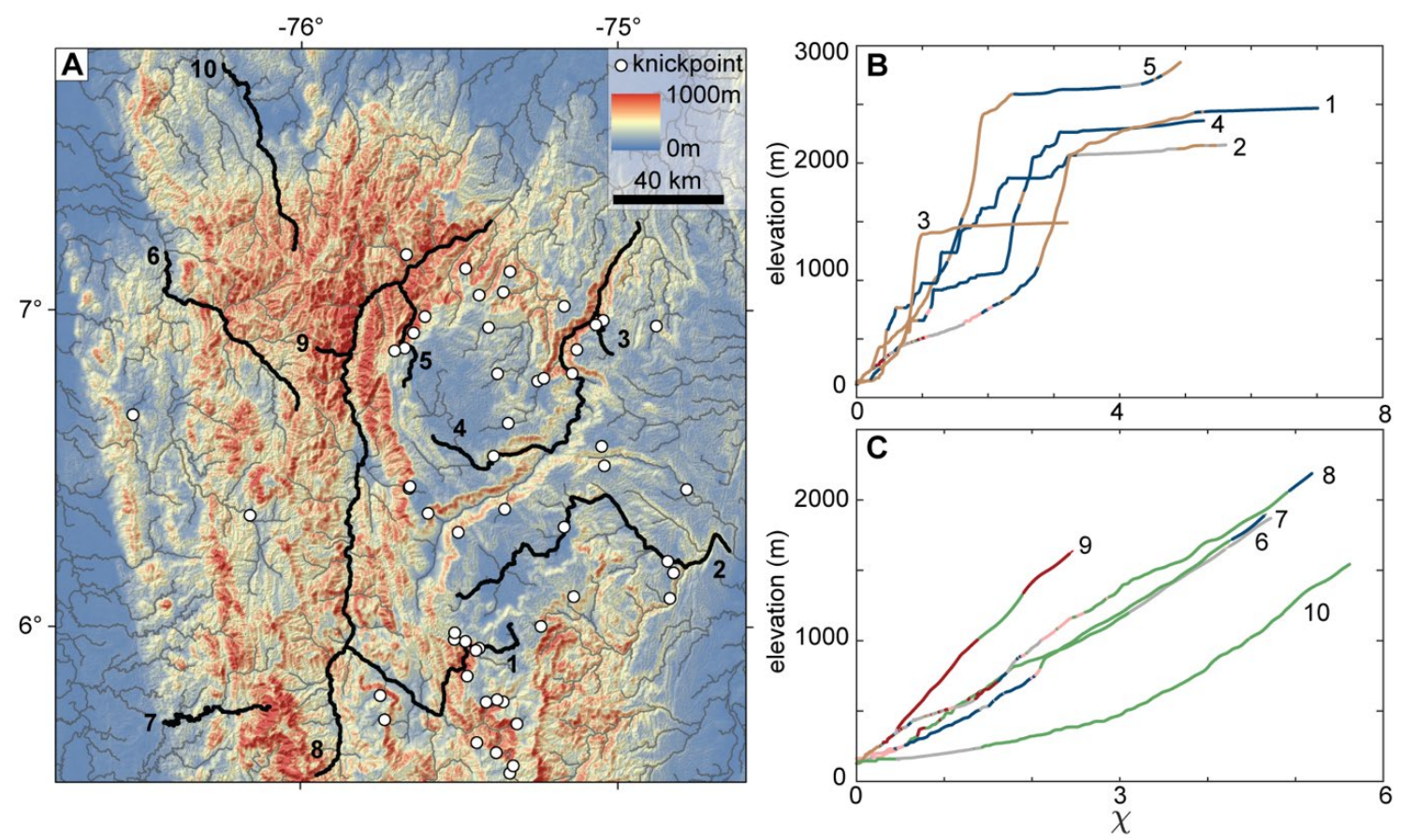

Fig. 5. $\chi$ profiles and knickpoints in the northern Central and Western Cordillera (Antioqueño Plateau area). A. Local relief map with knickpoint locations (white points) and stream network (black lines). B. Representative $\chi$-profiles of the Antioqueño Plateau area colored by lithology according to Fig. 1D. The streams are highlighted in (A). The location of knickpoints does not correspond to changes in lithology. C. Representative river profiles of the northern segment of the Western Cordillera. Most rivers in the Western Cordillera show well graded $\chi$-profiles indicative of equilibrium river profiles. Stream no. 10 highlights that the rivers in the northern flank of the Western Cordillera tend towards higher concavity values than the rest of the streams.
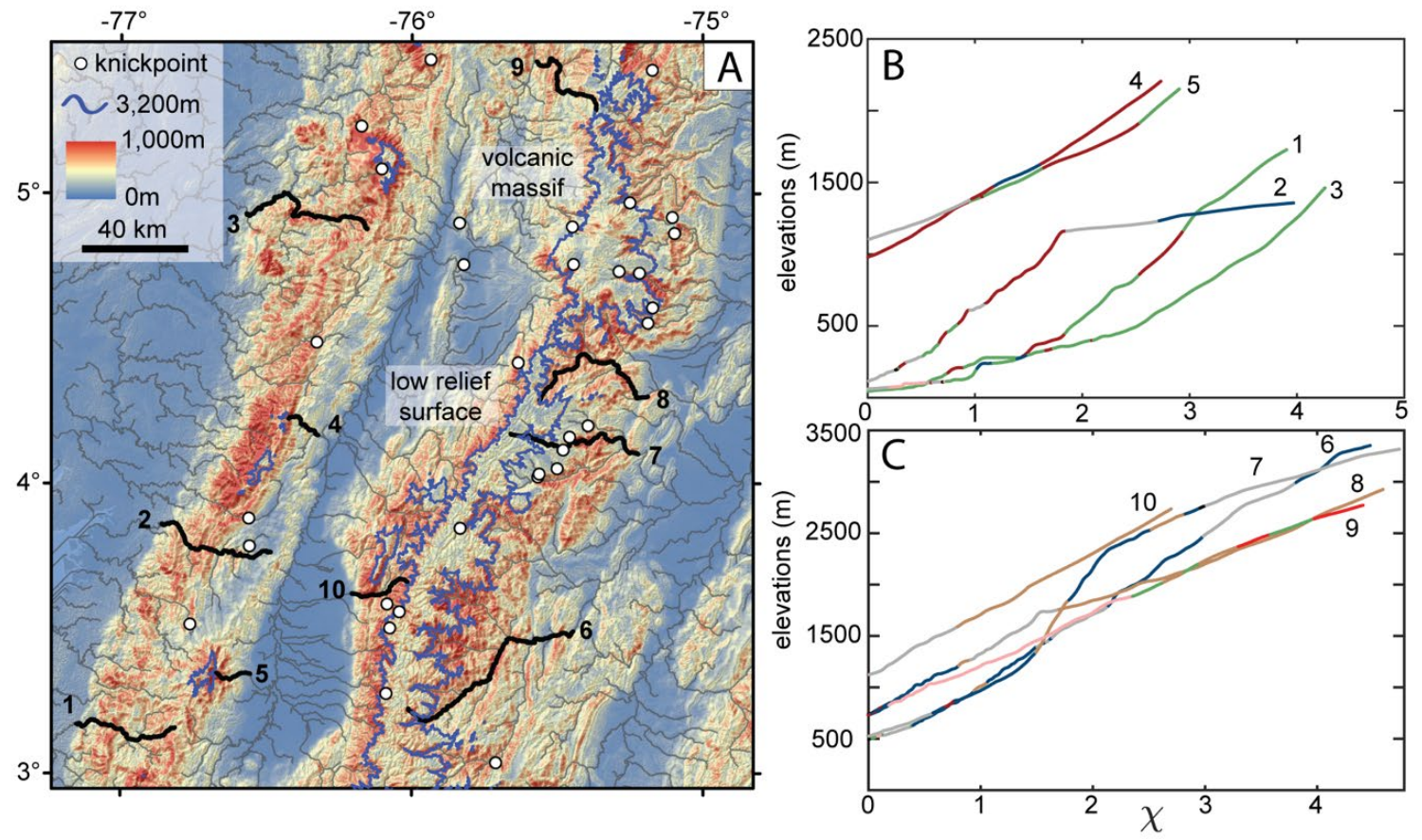

Fig. 6. $\chi$-profiles and knickpoints in the southern segment of the Central and Western Cordillera. A. Local relief map with knickpoint locations (white points) and stream network (black lines). Blue line indicates the 3,200m elevation contour. B. Representative $\chi$-profiles of the southern Western Cordillera. Most rivers in the Western Cordillera are in equilibrium. C. Representative $\chi$-profiles of the southern Central Cordillera colored by lithology according to Fig. 1D. Stream no. 7 traverses the low relief surfaces south of the city of Ibagué. 
South of the slab tear, fewer knickpoints occur and the river profiles draining the flanks of the Central Cordillera are mostly well graded (Fig. 6 A,B). In this part of the Central Cordillera the knickpoints are often located around the volcanic plateaus, e.g., of the Ruiz-Tolima Volcanic Massif. Pliocene and Quaternary volcanic rocks form lower gradient volcanic fields and infill valleys at the crest of the mountain range and the knickpoints are commonly located close to the transition from volcanic fields to the underlying basement rocks (Fig. 6A). In the southern Central Cordillera, a low relief region with knickpoints following its margin is located along the crest of the Andes. This low-relief area is bounded in the west by the Pijao Fault and may therefore be related to fault activity. However, ubiquitous u-shaped valleys above the knickpoints suggest that glaciation could have contributed to the lower gradient. Herd (1975) and Thouret et al. (1997) found that glaciers during the last glacial maximum, terminated mostly between 3000-3200 m, with some glaciers advancing down to $\sim 2700 \mathrm{~m}$ on the eastern flank. We highlight the $3200 \mathrm{~m}$ contour line in Fig. 6A and find that it mostly outlines the low-relief surfaces in the southern Central Cordillera. The Western Cordillera does not exhibit clear differences in its drainage network north and south of the slab tear. Drainages in the southern Western Cordillera are still mostly well graded with some knickpoints that may be attributed to lithology and some related to small-scale drainage reorganization (Fig. 6C).

\subsection{Cauca and Patía river profiles and erosion rate data}

The overall shape of the longitudinal profile of the main trunk of the Cauca River also shows differences across the slab tear (Fig. 7A). South of the slab tear, the Cauca River profile has a concave up shape and mostly flows with low gradient through a sedimentary intermontane basin. Close to the location of the proposed slab tear, the Cauca River steepens and enters the Cauca Canyon, where it keeps a consistent steepness throughout.

The Patía River profile is similar to the Cauca, where the river flattens past its headwaters to a base level that is $\sim 400 \mathrm{~m}$ lower than the Upper Cauca valley. As the Patía river starts flowing across the Western Cordillera, its profile steepens again, and the river forms a deep canyon. In the lower segment, higher channel steepness is likely related to the higher erosional resistance of the Western Cordillera basement rocks (Fig. 7A,B) and higher uplift rates past the orogen bounding thrust faults.

The differences in steepness, $\chi$, and other topographic metrics along the main river profiles are reflected in the erosion rate estimates from suspended load data (Fig. 7C). In the Cauca River Basin, the erosion rate at the lower gauge station, draining both the upper segment of the Cauca Basin and the steep Cauca Canyon, is three times higher than the rate at the Upper Cauca Valley (Fig. 7C). The lower pourpoint of the Cauca River Basin has a drainage area of $40,250 \mathrm{~km}^{2}$ and an average sediment yield of 1,580 $\mathrm{t} / \mathrm{km}^{2 *} \mathrm{y}$ 
$\left(\sigma=1,570 \mathrm{t} / \mathrm{km}^{2 *} \mathrm{y}\right)$, which corresponds to an erosion rate of $\sim 620 \pm 310 \mathrm{~m} / \mathrm{My}$. The upper pourpoint of the Cauca River Basin has a drainage area of $25,000 \mathrm{~km}^{2}$ and an average sediment yield of $500 \mathrm{t} / \mathrm{km}^{2 *} \mathrm{y}(\sigma=630$ $\mathrm{t} / \mathrm{km}^{2 *} \mathrm{y}$ ), which corresponds to an erosion rate of $\sim 200 \pm 100 \mathrm{~m} / \mathrm{My}$. The pour point of the Upper Patía River has a drainage area of $8,760 \mathrm{~km}^{2}$ and an average sediment yield of $1,410 \mathrm{t} / \mathrm{km}^{2 *} \mathrm{y}\left(\sigma=3,670 \mathrm{t} / \mathrm{km}^{2 *} \mathrm{y}\right)$, which corresponds to an erosion rate of $\sim 540 \pm 270 \mathrm{~m} / \mathrm{My}$. The Patía River has an erosion rate that is nearly 3 times higher than the upper segment of the Cauca River basin, thereby confirming the divide migration predicted by topographic metrics (Figs. 3A and 4B).
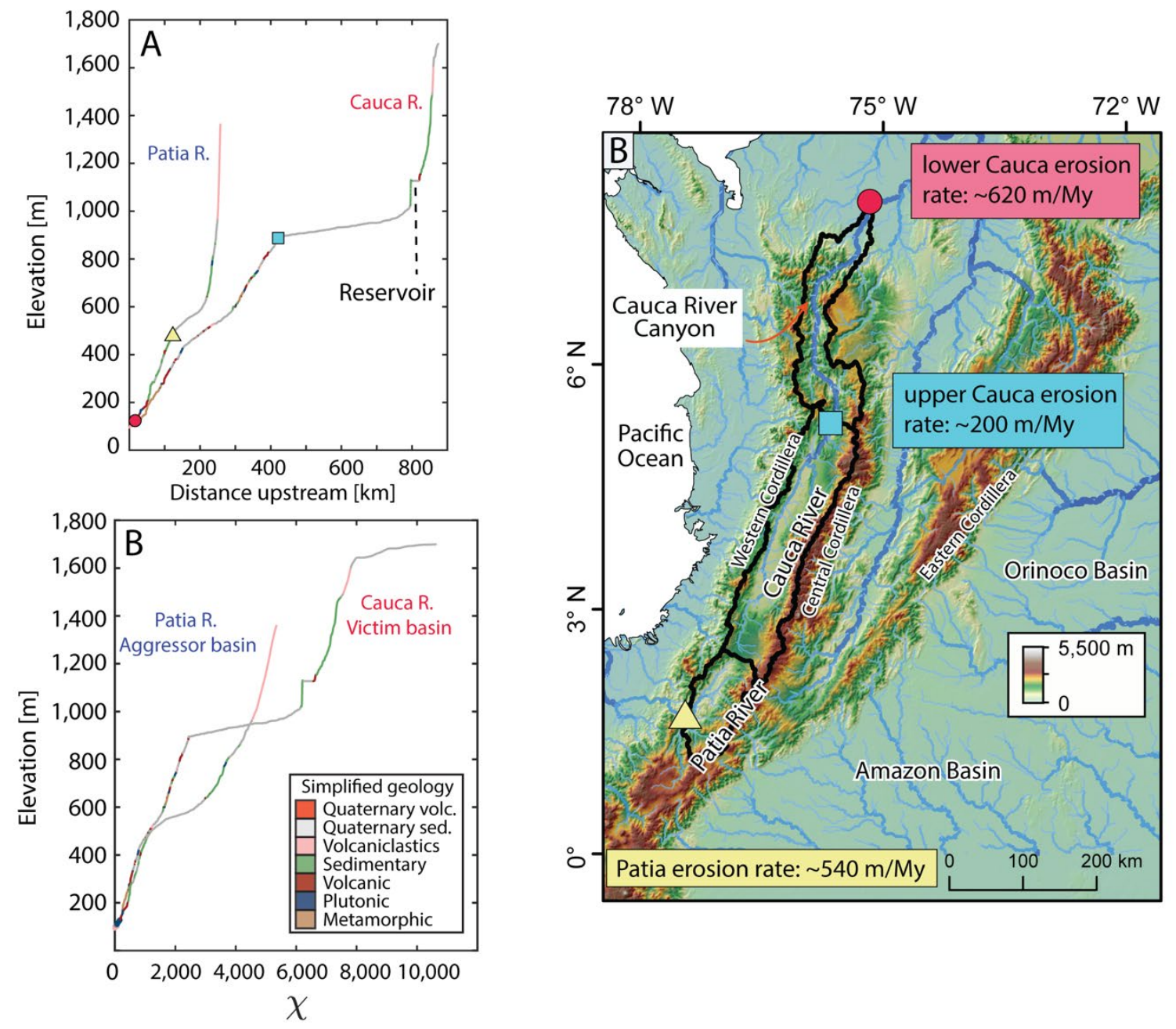

Fig. 7. Comparison of river profiles and erosion rates in the Patia and Cauca rivers. A. Elevation profiles of the Cauca and Patia Rivers B. $\chi$-profiles of the Cauca and Patía Rivers. C. Location of the gauge stations and catchments used to calculate erosion rates. 


\subsection{Evidence of Pliocene to modern basin infilling and incision in the Patía Basin}

Field observations as well as the geological map in Fig. 8B shows that in several areas of the Patía Basin, high volumes of Pliocene to Holocene lavas, pyroclastic and volcaniclastic rocks, sourced from the volcanic edifices to the Central Cordillera were deposited. These deposits bury paleo-topography and fill paleo-valleys (Fig. 8C-E). The emplacement of large volumes of volcanic rocks near the modern drainage divide between the Cauca and Patía rivers may have blocked and diverted streams. The Patía and its tributaries have incised hundreds of meters into these volcanic deposits and thereby present an opportunity to estimate fluvial incision rates within the Patía Basin.

The headwaters of the Patía and Cauca river are located in the Popayan Plateau (Fig. 8A). This

plateau is formed by Pleistocene-Quaternary lavas, pyroclastic and volcano sedimentary rocks that have a local thickness $>400 \mathrm{~m}$. Thus, they contributed significantly to the formation of the topography at the drainage divide. The timing of formation of the Popayan Plateau is constrained by Ar-Ar geochronology on the volcanic rocks of the Popayan Formation to $1.6 \pm 0.8$ to $2.9 \pm 0.3$ Ma (Figure 8B,C; Table S1; Risnes, 1995; Torres Hernández, 2010).

The Patía River is the only river that crosses the Western Cordillera and has a strong bend ("elbow"), where it deviates from the N-S structurally controlled flow and crosses the Western Cordillera through a narrow canyon (i.e., "Hoz de Minamá" canyon; Fig. 8A). The location of this canyon coincides with a local depression in the Western Cordillera, where remnants of perched volcanic deposits of Pleistocene age unconformably overlie the oceanic basement of the Western Cordillera (Fig. 8E,G,H) at elevations of $\sim 0.5 \mathrm{~km}$ above the modern channel. To the east, in the Juanambu Canyon (tributary of the Patía) a thick volcanic sequence has been deposited and now is being dissected by the Juanambu River (Fig. $8 \mathrm{D})$. The top of the volcanic deposits in the Juanambu Canyon is located $\sim 500 \mathrm{~m}$ above the modern river. The age of the volcanic deposits in the Hoz de Minamá and the Juanambu Canyon is largely unconstrained, but assuming a Pleistocene age (ca. $1.5 \pm 0.1 \mathrm{Ma}$ ) based on the correlation of these deposits with nearby ignimbrites (Murcia and Pichler, 1986; Murcia and Cepeda, 1991b), allows us to calculate an incision rate of $\sim 0.3 \mathrm{~km} / \mathrm{Myr}$ for both rivers since the emplacement of the volcanic deposits. 

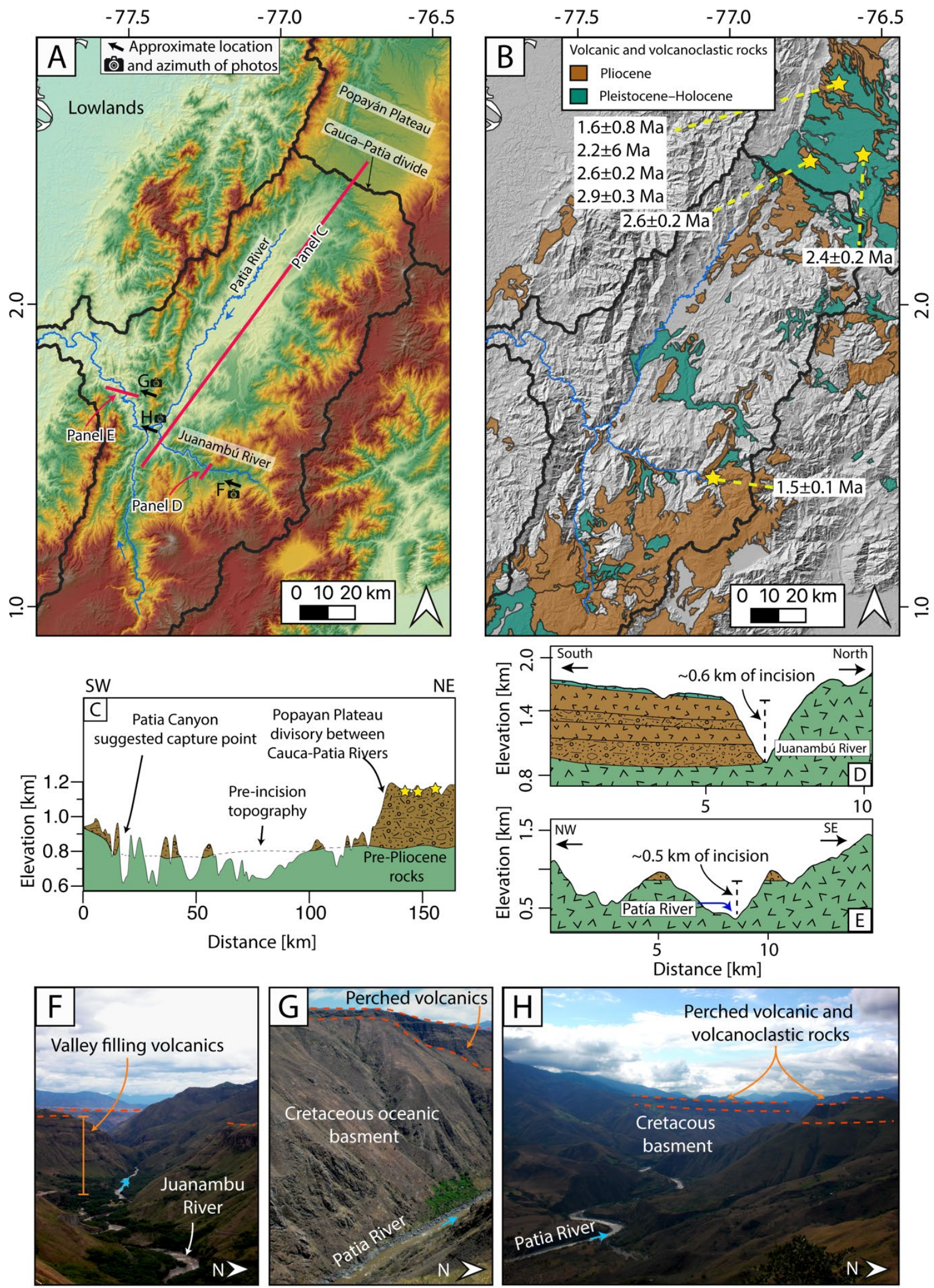
Fig. 8. Evidence of volcanic filling and subsequent incision in the Patia River catchment. A. Topography of the Patia River Basin labeled with main topographic features. Red lines indicate the location of the cross sections displayed in C-E. B. Hillshade with the location of Pliocene to Holocene volcanic rocks. Yellow stars highlight the locations of geochronology ages (Table S1). C. Approximately $N-S$ cross section across the Patia Basin showing the location and elevation of the Popayan Plateau and the valley filling volcanic deposits, now perched above the modern rivers. D. Cross section of the Juanambú River Canyon. E. Cross section of the Patia Canyon, where the river crosses the Western Cordillera F. View to the west of the Juanambu Canyon showing flat-lying valley-filling volcanics on the left. G-H. Views of the western wall of the Patia Canyon. Perched volcanic deposits can be seen unconformably overlying the Cretaceous oceanic basement of the Western Cordillera.

The cross section in figure $8 \mathrm{C}$ shows the relationship between the volcanic deposits of the Popayan Plateau and the other volcanics along the Patía River. The base of the Plio-Quaternary volcanic rocks of the Popayan plateau aligns with the elevations of the lava flows and volcaniclastics perched along and at the outlet of the Upper Patía Valley. The flat pre-volcanic topography resembles the low gradient of the Upper Cauca Valley just north of the Popayan Plateau. The lack of pre-volcanic topography along the modern drainage divide between the Cauca and Patía Rivers suggests that their drainage basins may have been connected before the emplacement of up to $400 \mathrm{~m}$ of volcanics. We hypothesize that the high rates of emplacement of volcanics around the Popayan Plateau could have disrupted a north-flowing paleo-PatíaCauca river in the Pleistocene and caused overflow of the Patía river into the Pacific Ocean. This capture would have substantially lowered base level in the Patía basin and caused the incision we documented along the Hoz de Minamá and the Juanambu Canyons; we further discuss this potential capture in section 5.2.

\subsection{Along strike orogen variations in river steepness and relation to precipitation rate of the Western}

\section{Cordillera}

In general, the Western Cordillera exhibits fairly constant normalized river channel steepness along its strike on both flanks (Fig. 9), with a steeper eastern flank along the Upper Patía basin and the lower Cauca Canyon. Channel steepness appears to be slightly steeper on the east (average west $k_{\mathrm{sn}}=184$, east $\mathrm{k}_{\mathrm{sn}}=266$ ), where basin average MAP is $\sim 2 \mathrm{~m} / \mathrm{yr}$, compared to western flank where basin average MAP is up to $8 \mathrm{~m} / \mathrm{yr}$. The precipitation corrected channel steepness $\left(k_{s n} \mathrm{P}\right)$ does not show a systematic offset between steepness of the eastern and western flank suggesting a potential precipitation effect on the steepness of the orogen topography. 
The river steepness along the Central Cordillera shows mostly steeper rivers on the western flank (Fig. 9, average west $\mathrm{k}_{\mathrm{sn}}=293$, east $\mathrm{k}_{\mathrm{sn}}=197$ ). Yet, in the Central Cordillera precipitation rates do not vary systematically across the mountain range (Fig. 9). In the northern Central Cordillera the steeper western flank is explained by the steep Cauca Canyon in the west, where uplift along the Romeral Fault is likely to be high. Whereas the eastern flank comprises a low relief surface gently sloping towards the Magdalena Valley, as documented by our swath-profiles (Fig. 2A). In the southern Central Cordillera, the western flank is also steeper than the eastern flank, however large amounts of Quaternary and Pliocene volcanics and volcaniclastics have been emplaced and deposited on the eastern flank and likely contributed to this asymmetry.
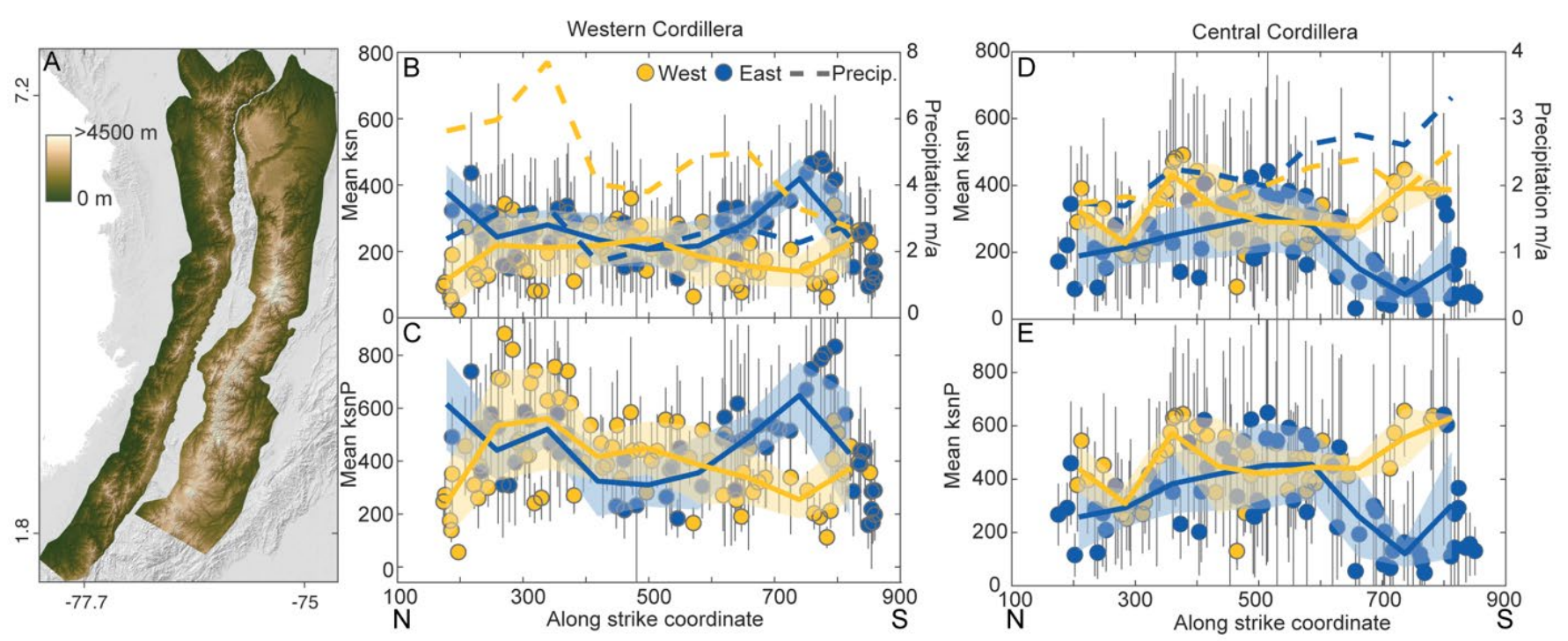

Fig. 9. Along strike variations in $k_{s n}$ and precipitation rates along the Central and Western Cordilleras. A. Clipped digital elevation models used for the calculations. Plots show mean basin $k_{s n}$ and standard deviations (points and error bars) for drainage basins with areas greater than $50 \mathrm{~km}^{2}$, along with a running mean of $k_{s n}$ (bold line) and basin precipitation rates (dashed lines) of 10 along strike bins, for the Western (B) and Central (D) Cordillera. $C$ and $E$ show the same with precipitation corrected $k_{s n}$ (see methods). BC. Channel steepness along the Western Cordillera is roughly constant with a peak in the south. The west side of the Western Cordillera receives a higher amount of precipitation compared to the east side and the uncorrected $k_{s n}$ seems to be flatter along strike. D-E. Plots for the Central Cordillera. Mean $k_{s n}$ does not vary markedly when corrected for precipitation amount. In the south, the Central Cordillera is very asymmetric where the topography appears to be controlled by Quaternary volcanism. In the north, the west side along the Cauca Canyon is steeper, probably highlighting higher rates of uplift that decrease towards the east. 


\section{Discussion}

Our geomorphic analysis shows spatial variations in topography and drainage network metrics along the Western and Central Cordilleras of the Northern Andes of Colombia. In the following sections we discuss the processes involved in driving these variations. We first discuss large-scale variations that may be linked to subduction geometry and subsequently discuss local variations linked to volcanism and climate. Finally, we discuss our findings in the context of the regional biodiversity.

\subsection{Topographic response to spatial and temporal changes in slab geometry}

\subsubsection{Landscape and river response}

We have documented a series of knickpoints surrounding low-relief high-elevation areas in the Central Cordillera, north of the slab tear. Given the absence of lithogic and climatic variations across knickpoints and considering their alignment in elevation (Fig. 5B), we interpret these knickpoints as indicators of a temporal change in uplift rate. South of the slab tear, rivers in the Central Cordillera are mostly well graded suggesting more constant rates of uplift through time. This is similar to the Western Cordillera, where $\chi$-profiles document roughly constant channel steepness in agreement with constant uplift through time. The interpretation of an increase in uplift rate north of the slab tear is supported by Cauca river profile. Close to the proposed location of the slab tear, the Cauca river steepness increases dramatically and transitions from the low gradient plains of the Upper Cauca valley to the up to $2.5 \mathrm{~km}$ deep Cauca Canyon (Fig. 7). This topographic change coincides with a downstream increase in catchment wide erosion rates observed in gauge data along the Cauca River which supports the idea of differences in rock uplift rates north and south of the slab tear. The uplift signal seems to decay towards the east, away from the Romeral Fault zone as indicated by the tilt of the east-sloping low relief region in our swath profiles (Fig. 2A) and the accompanying gradual lowering of knickpoint elevations (Fig. 5B).

Despite the trend of well graded rivers in the Central Cordillera south of the slab tear, we document two exceptions to this general behavior. The Ruiz-Tolima Volcanic Massif (Cordillera Central) encompasses an area of lower relief with several knickpoints. Here, the Pliocene to modern volcanic rocks form landscapes with lower gradients and infill paleo-valleys. Knickpoints are commonly located around these volcanic complexes, suggesting that the emplacement of volcanic rocks may be responsible for the observed topography. Another low relief surface with knickpoints is located in the southern Central Cordillera, south of the volcanic complexes (Fig. 6A). Its western border seems to follow the Silvia-Pijao Fault, suggesting that increased fault slip may have contributed to the uplift of this low relief region. It is noteworthy, that 
especially along the eastern margin of this area, river valleys are u-shaped, suggesting that glaciation of this region may have lowered the gradients of upper river reaches (e.g., Brocklehurst and Whipple, 2007) and may, therefore, be another contributor to the formation of low relief regions with knickpoints. The modern equilibrium line altitude (ELA) in the Ruiz-Tolima volcanic massif is located at ca. 5,100 m (see Thouret et al., 1997 and references therein). However, the glaciers terminated at elevations as low as ca. 2,9003,300 m during the last glacial maximum (Herd, 1975; Thouret et al., 1997). Based on the close correlation of this elevation band with the outline of the low-relief surfaces in the southern Cordillera Central, we propose that glaciers contributed to the observed lower gradient of high elevation topography.

\subsubsection{Drainage reorganization}

Our analysis shows that rivers draining the western flank of the northern Central Cordillera are capturing drainage area from east-flowing rivers perched on the Antiqueño Plateau. This is supported by differences in across divide $\chi$-values and topographic steepness values, yet additional evidence can be found along the Porce River. In contrast to all its tributaries, that exhibit major knickpoints as they flow onto the Antiqueño Plateau, the Porce River flows through a $>1 \mathrm{~km}$ deep canyon that cuts through the entire Antiqueño Plateau and suddenly ends without clearly defined headwaters (Fig. 10). The channel steepness of the upper Porce River is substantially lower than that of its tributaries or the neighboring Cauca Canyon. The occurrence of this deeply dissected valley without headwaters, in a region where divide migration towards the east is predicted, suggests that this is likely a drainage capture location, where the Porce was once part of the paleo-Cauca river. Now, the Porce River is a minor stream that flows through a $>1 \mathrm{~km}$ deep canyon referred to as the Aburra Valley, the only canyon crossing the entire AP. This suggests a river greatly exceeding the erosive power of its neighboring streams carved this valley (Fig. 10). We therefore hypothesize that the Aburra Valley is where the paleo-Cauca River flowed before and during the initial increase of uplift rate. As the largest river of this region, the paleo-Cauca River would have had the erosional power to carve this canyon, after the onset of the increase in uplift rate. At some point, uplift along the Romeral Fault Zone likely exceeded the erosional capacity of the paleo-Cauca or it was captured by headward erosion of a stream following the path of the modern Cauca Canyon. The uneroded steep canyon walls of the Aburra Canyon and the lack of tributary incision suggest that the formation of this canyon was comparatively recent and fast. If the hypothesis is correct, this capture would have shifted the locus of sedimentation at the outlet of the Cauca River by about $60 \mathrm{~km}$ to the west (Fig. 10).

Previous thermochronological work in the walls of the Aburra Valley revealed older Paleogene AHe and AFT ages but was unable to reveal the age of incision of the canyons (Saenz, 2003; RestrepoMoreno et al., 2009) We speculate that the absence of younger ages in the Porce River Canyon could be 
explained if its incision was recent $(<10 \mathrm{Ma})$ but the magnitude of incision $(\sim 1 \mathrm{~km})$ was insufficient to reach the younger cooling ages below the pre-incision Partial Retention (or Annealing) Zone (e.g., Fitzgerald and Malusà, 2019 and references therein).
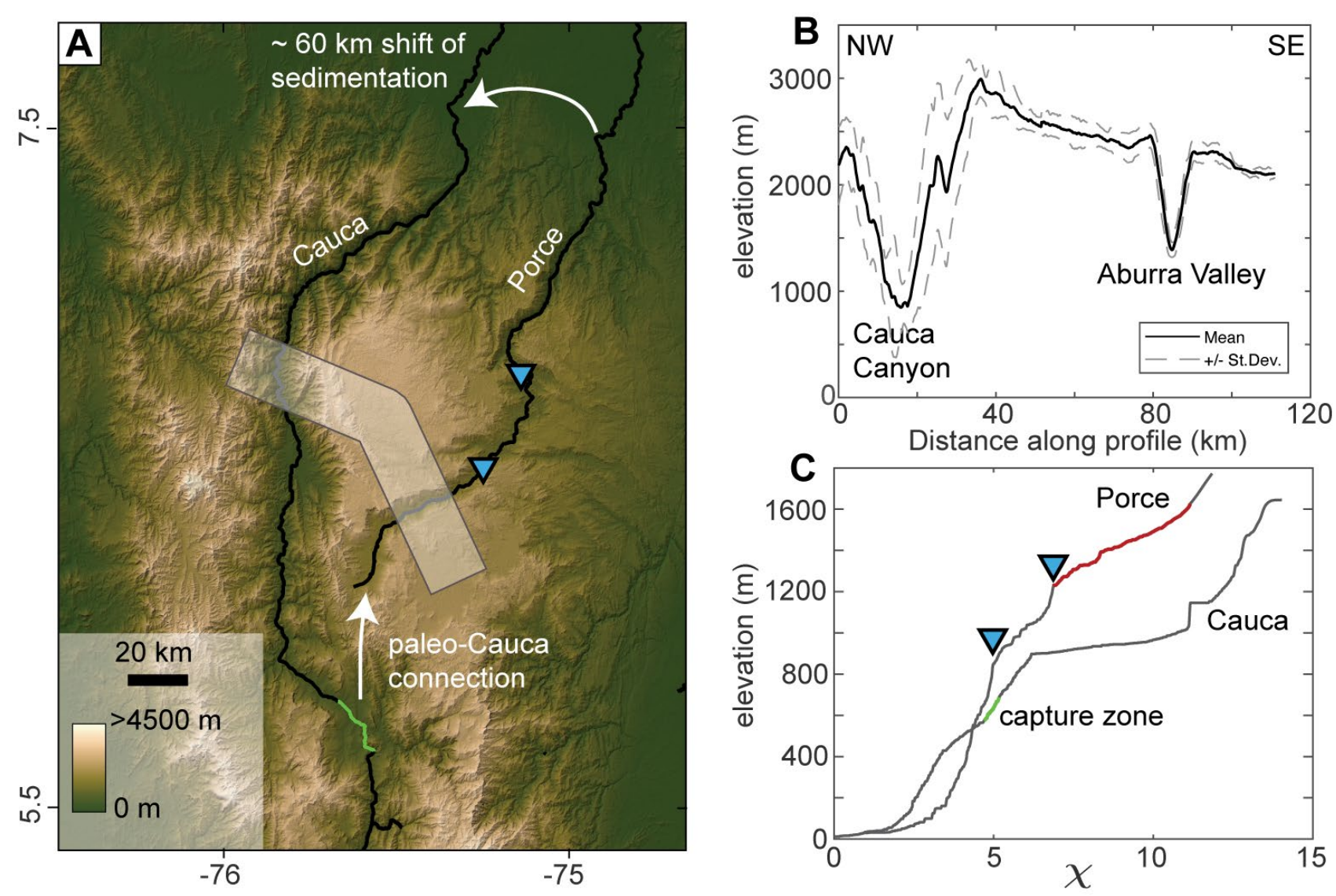

Fig. 10. Cauca-Porce capture hypothesis. A. Location of proposed capture and paleo-Cauca flow path. Blue triangles mark the locations of knickpoints in the Porce River profile in panel C. The white box indicates the location of the swath profile and the green river segment indicates the estimated capture zone. Note the abrupt end of the deeply incised Porce River canyon, suggesting a missing headwater area. B. Swath profile across the Cauca Canyon and Porce River Canyon (Aburra Valley). C. $\chi$ vs. elevation profiles of the Cauca and Porce rivers. Red line indicates the portion of the Porce River profile that could correspond to the approximate pre-capture paleo-Cauca profile. 


\subsubsection{Slab flattening as probable cause for uplift rate change and comparison with previous studies}

From our topographic analysis we infer a recent increase in uplift rate in the northern Central Cordillera. Neogene tectonic events in this region that may have caused this change, include the collision Panamá-Chocó block (15-12 Ma; Farris et al., 2011; Montes et al., 2012, 2015; León et al., 2018) and flattening of the subducting slab <9 Ma ago (Wagner et al., 2017). The differences we observed in river profiles and relief distribution along the Central Cordillera and Cauca Valley, show a close spatial correlation with the proposed location of the slab tear and the main area of slab flattening (Fig. 11). Whereas, we did not find topographic differences along the Western Cordillera that correlate with proximity to the Panamá-Chocó block collision zone. Therefore, we propose that slab flattening in the northernmost part of the Nazca subduction zone caused an increase of uplift in the Northern Cordillera Central. The Western Cordillera is located at the edge of the slab tear, trenchward of the Central Cordillera. We hypothesize that geometric changes of slab geometry below the Western Cordillera were minor, resulting in no clear along-strike differences in topography.

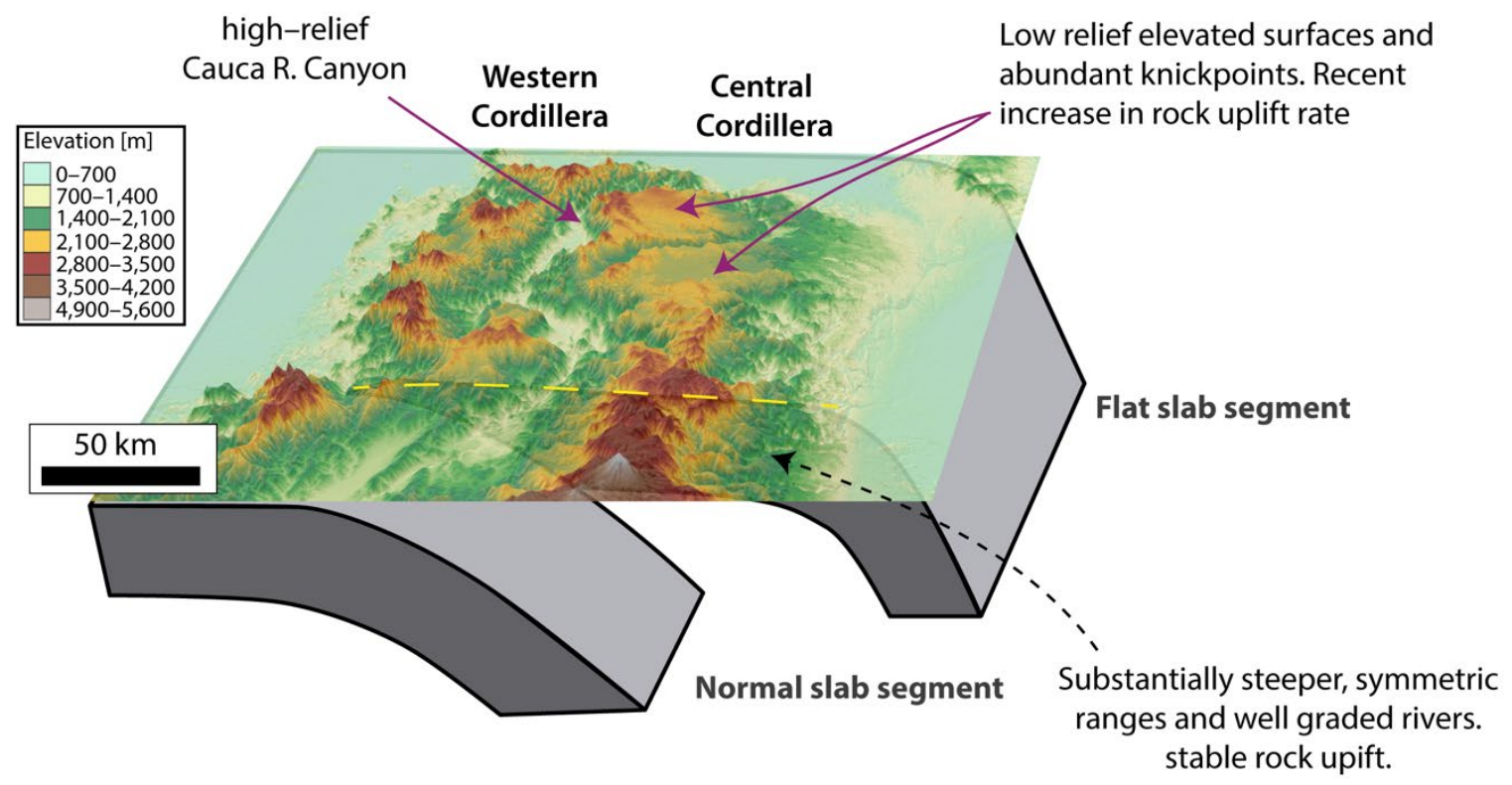

Fig. 11. Topographic response of the Western and Central cordilleras to variations in slab geometry.

Flat slab subduction has been shown to increase the coupling between tectonic plates and in response increase crustal shortening that may induce surface uplift (Espurt et al., 2008; Eakin et al., 2014). Furthermore, numerical modelling and field observations in the Peruvian flat slab have documented that 
the transition from normal to flat slab subduction may result in a "dynamic uplift" from isostatic adjustments of $>1.5 \mathrm{~km}$ in the region directly above the flat slab (Eakin et al., 2014). The elevation of the Antioqueño Plateau today is $\sim 2.5 \mathrm{~km}$ and plateau relief only a few hundred meters. Therefore, the total recent surface uplift can be assumed to be on the order of $\sim 2 \mathrm{~km}$. This is in good agreement with the predictions from dynamic uplift (Eakin et al., 2014) with a likely contribution from increased crustal thickening.

The hypothesis proposed here challenges the view that the Central Cordillera can be regarded as an old orogen with topography mostly established by the Paleogene (Gómez et al., 2003; Bande et al., 2012; Nie et al., 2012; Villagómez and Spikings, 2013; Mora et al., 2020). We speculate that topography in the southern Cordillera Central is indeed "old” (e.g., Villamizar-Escalante et al., 2021), whereas the topography in the northern Cordillera Central has only been growing since the Late Miocene to Pliocene. Yet, previous studies relying on thermochronology data were not able to identify this recent episode of mountain building, because uplift is too recent for the rivers in this region to have equilibrated their profiles and created sufficient incision.

The interactions between the deep processes such as flat-slab subduction and surface processes are a topic of debate. Some studies in the Andes have found that the onset of flat slab subduction correlated with upper plate deformation (Jordan et al., 1983; Ramos and Folguera, 2009; Margirier et al., 2015). However, other recent papers in the Andes with robust geo- and thermochronology data have argued that the timing and spatial patterns of deformation pre-date the onset of flat slab subduction in the southern Andes (Buelow et al., 2018; Lossada et al., 2020).

Our landscape analysis in the Northern Andes shows that a major change in rock uplift rate in the northern Central Cordillera occurred as a result of the onset of flat-slab subduction north of $5^{\circ} \mathrm{N}$. In fact, other geological information suggests a pulse of surface uplift of the northern segments of the Central and Western Cordilleras in the Neogene. For example, a recent study on the western flank of the Central Cordillera showed one thermal history model based on AFT thermochronology that shows an increase in exhumation at $\sim 10$ Ma (Duque-Palacio et al., 2021). A provenance analysis from the adjacent Middle Magdalena Valley, to the east of the Central Cordillera, shows the appearance of a substantial proportion of detrital zircons with $\mathrm{U}-\mathrm{Pb}$ ages $<100 \mathrm{Ma}$ in the upper Miocene Real Formation (Horton et al., 2015). These detrital zircons likely reflect contributions from Cretaceous to Paleogene igneous sources, typical of the rocks in the northern Central Cordillera and Western Cordillera (Horton et al., 2015). An AHe age of 3.9 $\mathrm{Ma}$ in an Eocene batholith, that runs parallels to the Western Cordillera suggests active exhumation in the late Miocene-Pliocene (Villagómez and Spikings, 2013). Also, the detrital AFT age distribution of a 
sample from the western flank of the Western Cordillera has a significant Miocene age peak, with a handful of grains as young as 4.5 Ma (León et al., 2018). The effects of flat-slab subduction have also been documented in the Eastern Cordillera as an increase in the rates of exhumation at 7.5 Ma (Siravo et al., 2019).

\subsection{Drainage reorganization caused by volcanism}

In the area near the Cauca-Patía divide, volcanism plays an important role in ongoing drainage reorganization through the development of a Quaternary volcanic plateau that acts as a barrier, separating the upper Cauca from the upper Patía basins. Today, the differences in $\chi$, channel steepness and hillslope gradient across the Cauca-Patía divide suggest that the Patía Basin is capturing drainage area from the headwaters of the Cauca River (Figs. 3,4). The presence of highly dissected Pliocene-Quaternary volcanic deposits in the Patía River catchment implies active fluvial incision consistent with the high erosion rate in the Upper Patía Basin ( $540 \mathrm{~m} / \mathrm{Myr}$ ) derived from gauge data. Erosion rates in the adjacent Cauca basin are nearly a factor of 3 lower (Fig. 7). Gauge derived erosion rate estimates may be higher than the true values due to land degradation and deforestation (Restrepo and Cantera, 2013), but without cosmogenic nuclide derived erosion rates, these serve as a first order estimate.

We explain the high erosion rate and low $\chi$ values of the Patía river, as part of a transient wave of erosion resulting from the capture of a segment of the southern extreme of the ancient Cauca river (Fig. 12). The pre-volcanic topography of the Upper Patía Valley and the area of the Patía-Cauca drainage divide have very low gradients. This is in contrast with the modern topography, where the Upper Patía Valley shows substantially higher relief and slopes compared to the Upper Cauca Valley. The change in topography since the late Pliocene to Pleistocene between the Upper Cauca and Upper Patía Valleys supports the idea of drainage capture. Faulting and differential vertical movement after the emplacement of volcanic rocks may have affected the reconstructed pre-volcanic topography (Fig. 8C, 12A,B), yet the geologic map does not show any faults with significant throw throughout the Quaternary along our profile line (Gómez et al., 2015). Moreover, the alignment in elevation of volcanic rocks perched above the outlet of the Upper Patía Valley and the thick Popayan Plateau volcanic sequence, suggests that capture of the Patía River from a paleo-Patía-Cauca river is feasible (Fig. 12). 


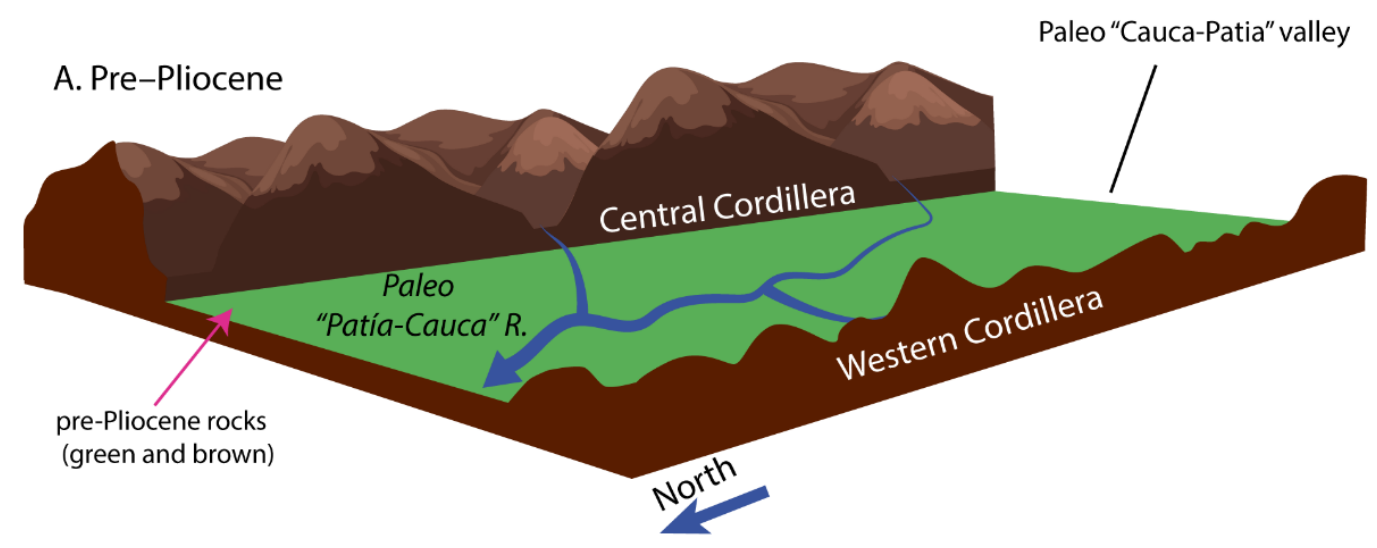

Paleo-valley filled with

volcanic (orange) rocks and later incised
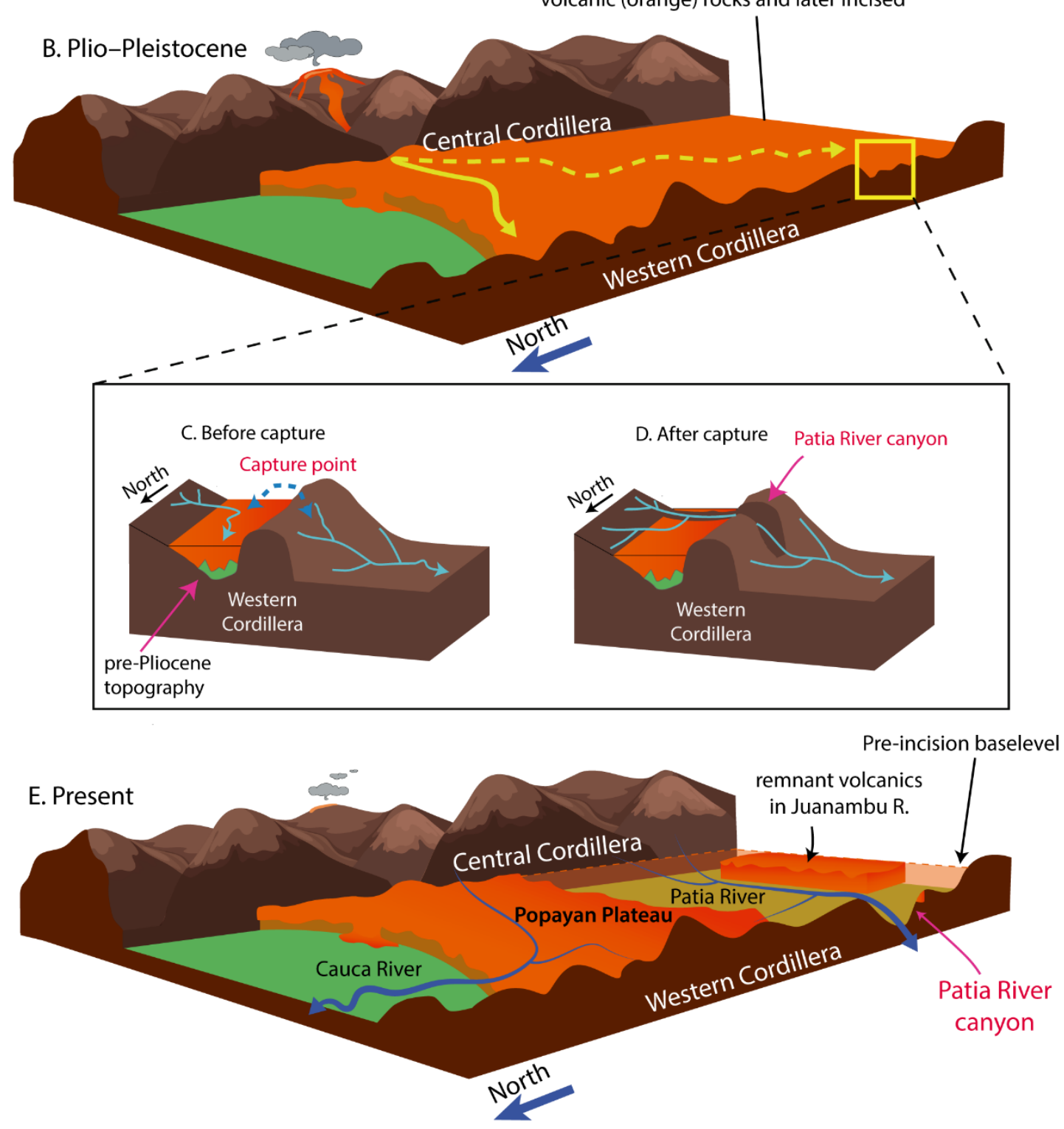
Fig. 12. Schematic hypothesis for the evolution of the Patia Basin. A. Schematic view of the pre-Pliocene paleo "Cauca-Patia" valley when the basins were connected and occupied by a north flowing paleoCauca-Patia river. B. Deposition of large volumes of volcanic and volcaniclastic rocks in the Pliocene and Pleistocene sourced from volcanic edifices in the Central Cordillera, especially in the area of the Popayan Plateau. C-D. Schematic hypothesis of the capture of the Patia Basin via spillover as a result of the increase in base level following the emplacement of the volcanic deposits. E. Schematic view of the volcanic Popayan Plateau forming the topographic divide between the Cauca and Patia rivers. Notice how the level of volcanic deposits extended towards the Patia Basin.

Two mechanisms offer plausible explanations for the capture of the ancient Cauca's headwaters (e.g., Larson et al., 2017): (1) Basin overflow or spillover. In this scenario, the high rates of volcaniclastic infilling of the Patía drainage basin during the Pliocene to Quaternary would have caused a spill-over towards the Pacific basin, creating a connection between the Pacific and the former Upper Cauca Basin through a low point in the Western Cordillera; or (2) A river draining the western flank of the Western Cordillera eventually captured the former Cauca-Patía drainage basin through headward erosion.

Initially, the Patía-Cauca River would have flowed N-S following geological structures as the Cauca River today does over most of its course without a connection to the Pacific Ocean. Drainage capture to the Pacific would have lowered the base level of the Patía significantly. This is supported by the deep incision of volcanic rocks perched above the canyons of the Patía and its tributaries (Fig. 8D, E) and contrasts the Cauca intermontane basin that is actively alluviating. Evidence for a former fluvial connection between the Cauca and Patía Rivers was suggested previously based on the geomorphic evidence (e.g., Padilla and Leon, 1989) and the similarity amongst the fish faunas in both basins (e.g., Maldonado-Ocampo et al., 2005, 2012). According to Maldonado-Ocampo et al. (2005) eleven species of fish are shared between the upper Cauca and Patía Basins. A modern analogue for a low point in the Western Cordillera that could lead to drainage capture can be found near the city of Cali (Fig. S3), where the distance between the drainage divide and the Cauca River is $<5 \mathrm{~km}$.

\subsection{Potential influence of precipitation on the topography of the Western and Central Cordillera}

We find that channel steepness in the Northern Andes is controlled by the rate of rock uplift, where higher steepness is found in areas of higher rock uplift. However, in the Western Cordillera, rivers on the eastern, drier flank exhibit higher average $\mathrm{k}_{\mathrm{sn}}$ than those of wetter, western flank; a difference which is reduced after estimating the discharge-corrected $\mathrm{k}_{\mathrm{sn}} \mathrm{P}$. The Western Cordillera is quite homogenous in lithology and comprises mostly Cretaceous marine sedimentary and volcanic rocks (e.g., Gómez et al., 2015), suggesting that this difference is unrelated to lithology. 
These observations hint that precipitation may exert an influence on basin steepness across the precipitation gradient in the Western Cordillera with higher channel steepness on the drier eastern flank compensating for overall lower discharge. The difference could also be explained by gradients in rock uplift rate; however, in the absence of uplift and erosion rate data, it is not possible for us to differentiate which factor plays the dominant role.

\subsection{Implications of recent topographic growth and drainage reorganization on the biodiversity of the}

\section{Northern Andes}

We have provided evidence for changes in topography and drainage reorganization associated with the onset of flat-slab subduction and volcanism that may have impacted biodiversity in the Northern Andes. The implications of our findings can be tested using species distribution or phylogenetic data (e.g., Baker et al., 2014). Prior to the onset of the flat-slab subduction, the northern Central Cordillera was a low-lying tropical environment. This is supported by the low relief of the Antioqueño Plateau, slow exhumation rates from thermochronology (Restrepo-Moreno et al., 2009; Villagómez and Spikings, 2013), and palynology from the Pliocene Mesas Formation (Dueñas and Castro, 1981). Since the onset of flat subduction at ca. 4$8 \mathrm{Ma}$ this region went from tropical lowlands to $\sim 2.5 \mathrm{~km}$ elevation at a minimum rate of $250 \mathrm{~m} / \mathrm{Ma}$. The uplift of the northern Central Cordillera may have isolated former lowland species at high elevations and led to an increased heterogeneity of the landscape by generating a wide variety of climates and ecosystems.

In fact, the Antioqueño Plateau is a place of high alpha biodiversity (Graham et al., 2018) and a distinct biogeographic region within the Central Cordillera (Hazzi et al., 2018). Furthermore, pool-water species fish documented on the Antioqueño Plateau lack the ability to disperse from the tropical lowlands along steep mountain rivers (Jaramillo-Villa et al., 2010), along with a generally high degree of fish endemism (Tognelli et al., 2016). This high diversity was enigmatic for ecologists in the past because the older thermochronology ages of the northern Central Cordillera were interpreted as low exhumation rates and little topographic change in the past ca. $25 \mathrm{Ma}$ (Graham et al., 2018). Therefore, other factors such as nutrient rich soils (Hermelin, 2015) derived from igneous rocks and a quaternary volcanic horizon in the Central Cordillera were suggested as factors that could contribute to the high regional diversity (Graham et al., 2018). With our data we show that the recent ( $<10 \mathrm{Ma})$ uplift of the northern segment of the Central Cordillera likely contributed to these biodiversity patterns. Moreover, events of drainage capture and reorganization can create new habitat connections and barriers for aquatic species and lead to speciation (e.g., Stokes and Perron, 2020). This could explain the shared distribution of species in between the upper segments of the Cauca and Patía rivers (Maldonado-Ocampo et al., 2005, 2012). 


\section{Conclusions}

In this paper we used geomorphic observations to understand how the topography of the Central and Western cordilleras of the Northern Andes were affected by recent changes in slab geometry, climatic and drainage reorganization. We find the following conclusions:

1. The northern segment of the Central Cordillera is characterized by an elevated low-relief surface with roughly uniform lithology and surrounded by multiple knickpoints. The transition to this topography coincides with an increase in channel steepness and erosion rates along the Cauca River. These geomorphic features suggest a recent increase in rock and surface uplift rate in the northern Central Cordillera.

2. Slab flattening north of $5^{\circ} \mathrm{N}$ is the most likely cause of the recent $\sim 2 \mathrm{~km}$ of surface uplift since 8 $4 \mathrm{Ma}$ in the northern Central Cordillera.

3. Large scale drainage reorganization of major rivers has occurred in the Northern Andes in the past $10 \mathrm{Ma}$. In the northern segment of the ranges the drainage reorganization is driven by changes in upper plate deformation in relation to development of the flat slab subduction geometry. However, to the south of the range other factors such as emplacement of volcanic rocks likely play important roles in this process.

4. In the Northern Andes the rate of rock uplift drives the steepness of the landscape, with higher steepness usually associated with higher fault-controlled rock uplift. However, we also found a relationship in the Western Cordillera, where precipitation rates appear to influence slopes. The catchments on the wetter western flank of the Western Cordillera have lower slopes than the catchments on the drier eastern flank.

5. Changes in the elevation of the northern Central Cordillera and the Pliocene to modern drainage reorganization in the Cauca and Patía basins are likely drivers of freshwater fish diversification and, more generally, of high alpha diversity regionally.

\section{Supplementary information is appended at the end of this document.}

\section{Acknowledgements}

Thanks to A. Mora, C. Do Nascimento, C. Montes, D. Scherler, S. Echeverri for discussions regarding geological and biological aspects of the study area. We thank the late J. Maldonado for his work 
with Andean freshwater fish that inspired us. M. Rodríguez, A. Fernandez, A. Cuervo and A. RodríguezCorcho for help making observations during the field work. Thanks to S. Rios for help with figures. N.P. was funded by the National Geographic Early Career Grant (EC-51182R-18), a Syracuse University Graduate Fellowship, the Syracuse University REDF Fellowship and Nelson Summer Research Fund from the Department of Earth and Environmental Sciences. The work of J.P.G. and J.V.P. was founded by the Spanish Ministry of Science and Innovation (MICINN) through the projects "PID2019-107138RB-I00 / AEI / 10.13039/501100011033" and "RYC-2017-23335". R.O. is funded by a Swiss National Science Foundation fellowship, grant number P2EZP2_191866.

\section{References}

Adams, B.A., Whipple, K.X., Forte, A.M., Heimsath, A.M., and Hodges, K. V., 2020, Climate controls on erosion in tectonically active landscapes: Science Advances, v. 6, doi:10.1126/sciadv.aaz3166.

Alfonso, C.A., Sacks, P.E., Secor, D.T., Rine, J., and Perez, V., 1994, A tertiary fold and thrust belt in the Valle del Cauca Basin, Colombian Andes: Journal of South American Earth Sciences, v. 7, p. 387402, doi:10.1016/0895-9811(94)90023-X.

Antonelli, A. et al., 2018, Geological and climatic influences on mountain biodiversity: Nature Geoscience, v. 11, p. 718-725, doi:10.1038/s41561-018-0236-z.

Antonelli, A., and Sanmartín, I., 2011, Why are there so many plant species in the Neotropics? Taxon, v. 60, p. 403-414, doi:10.2307/41317138.

Aspden, J.A., and McCourt, W.J., 1986, Mesozoic oceanic terrane in the central Andes of Colombia: Geology, v. 14, p. 415-418, doi:10.1130/0091-7613(1986)14<415:motitc>2.0.co;2.

Aspden, J.A., McCourt, W.J., and Brook, M., 1987, Geometrical control of subduction-related magmatism: the Mesozoic and Cenozoic plutonic history of Western Colombia: Journal of the Geological Society, v. 144, p. 893-905, doi:10.1144/gsjgs.144.6.0893. 
Badgley, C. et al., 2017, Biodiversity and Topographic Complexity: Modern and Geohistorical Perspectives: Trends in Ecology and Evolution, v. 32, p. 211-226, doi:10.1016/j.tree.2016.12.010.

Baker, P.A., Fritz, S.C., Dick, C.W., Eckert, A.J., Horton, B.K., Manzoni, S., Ribas, C.C., Garzione, C.N., and Battisti, D.S., 2014, The emerging field of geogenomics: Constraining geological problems with genetic data: Earth-Science Reviews, v. 135, p. 38-47, doi:10.1016/j.earscirev.2014.04.001.

Bande, A., Horton, B.K., Ramírez, J.C., Mora, A., Parra, M., and Stockli, D.F., 2012, Clastic deposition, provenance, and sequence of Andean thrusting in the frontal Eastern Cordillera and Llanos foreland basin of Colombia: Bulletin of the Geological Society of America, v. 124, p. 59-76, doi:10.1130/B30412.1.

Brocklehurst, S.H., and Whipple, K.X., 2007, Response of glacial landscapes to spatial variations in rock uplift rate: Journal of Geophysical Research, v. 112, p. F02035, doi:10.1029/2006JF000667.

Buelow, E.K., Suriano, J., Mahoney, J.B., Kimbrough, D.L., Mescua, J.F., Giambiagi, L.B., and Hoke, G.D., 2018, Sedimentologic and stratigraphic evolution of the Cacheuta basin: Constraints on the development of the Miocene retroarc foreland basin, south-central Andes: Lithosphere, v. 10, p. 366391, doi:10.1130/L709.1.

Carretier, S., Tolorza, V., Regard, V., Aguilar, G., Bermúdez, M.A., Martinod, J., Guyot, J.L., Hérail, G., and Riquelme, R., 2018, Review of erosion dynamics along the major N-S climatic gradient in Chile and perspectives: Geomorphology, v. 300, p. 45-68, doi:10.1016/j.geomorph.2017.10.016.

Cediel, F., Shaw, R.P., and Cáceres, C., 2005, Tectonic assembly of the Northern Andean Block: AAPG Memoir, p. 149-152.

Chiarabba, C., De Gori, P., Faccenna, C., Speranza, F., Seccia, D., Dionicio, V., and Prieto, G.A., 2016, Subduction system and flat slab beneath the Eastern Cordillera of Colombia: Geochemistry, Geophysics, Geosystems, v. 17, p. 16-27, doi:10.1002/2015GC006048. 
Dueñas, H., and Castro, G., 1981, Asociación palinológica de la Formación Mesa en la región de Falán, Tolima, Colombia.: Geología Norandina, v. 3, p. 27-36.

Duque-Caro, H., 1990, Neogene stratigraphy, paleoceanography and paleobiogeography in northwest South America and the evolution of the Panama seaway: Palaeogeography, Palaeoclimatology, Palaeoecology, v. 77, p. 203-234, doi:10.1016/0031-0182(90)90178-A.

Duque-Palacio, S., Seward, D., Restrepo-Moreno, S.A., and García-Ramos, D., 2021, Timing and rates of morpho-tectonic events in a segment of the Central and Western cordilleras of Colombia revealed through low-temperature thermochronology: Journal of South American Earth Sciences, v. 106, p. 103085, doi:10.1016/j.jsames.2020.103085.

Eakin, C.M., Lithgow-Bertelloni, C., and Dávila, F.M., 2014, Influence of Peruvian flat-subduction dynamics on the evolution of western Amazonia: Earth and Planetary Science Letters, v. 404, p. 250 260, doi:10.1016/j.epsl.2014.07.027.

Echeverri, S., Cardona, A., Pardo, A., Monsalve, G., Valencia, V.A., Borrero, C., Rosero, S., and López, S., 2015, Regional provenance from southwestern Colombia fore-arc and intra-arc basins: Implications for Middle to Late Miocene orogeny in the Northern Andes: Terra Nova, v. 27, p. 356363, doi:10.1111/ter.12167.

Espurt, N., Funiciello, F., Martinod, J., Guillaume, B., Regard, V., Faccenna, C., and Brusset, S., 2008, Flat subduction dynamics and deformation of the South American plate: Insights from analog modeling: Tectonics, v. 27, p. 1-19, doi:10.1029/2007TC002175.

Farris, D.W., Jaramillo, C., Bayona, G., Restrepo-Moreno, S.A., Montes, C., Cardona, A., Mora, A., Speakman, R.J., Glascock, M.D., and Valencia, V., 2011, Fracturing of the Panamanian Isthmus during initial collision with South America: Geology, v. 39, p. 1007-1010, doi:10.1130/G32237.1.

Fitzgerald, P.G., and Malusà, M.G., 2019, Concept of the Exhumed Partial Annealing (Retention) Zone and 
Age-Elevation Profiles in Thermochronology, in Malusà, M.G. and Fitzgerald, P.G. eds., Cham, Springer International Publishing, Springer Textbooks in Earth Sciences, Geography and Environment, p. 165-189, doi:10.1007/978-3-319-89421-8_9.

Flint, J.J., 1974, Stream gradient as a function of order, magnitude, and discharge: Water Resources Research, v. 10, p. 969-973, doi:10.1029/WR010i005p00969.

Forte, A.M., and Whipple, K.X., 2018, Criteria and tools for determining drainage divide stability: Earth and Planetary Science Letters, v. 493, p. 102-117, doi:10.1016/j.eps1.2018.04.026.

Gallego-Ríos, A.F., Pardo-Trujillo, A., López-Plazas, G.A., and Echeverri, S., 2020, The Morales Formation (new unit): Record of fluvial-lacustrine environments and the beginning of the Miocene explosive volcanism in the Patía Sub-basin (SW Colombia), in Gómez, J. and Mateus-Zabala, D. eds., The Geology of Colombia, Volume 3 Paleogene - Neogene., Bogotá, p. 395-415, doi:10.32685/pub.esp.37.2019.13.

Garzione, C.N. et al., 2017, Tectonic Evolution of the Central Andean Plateau and Implications for the Growth of Plateaus: Annual Review of Earth and Planetary Sciences, v. 45, p. 529-559, doi:10.1146/annurev-earth-063016-020612.

Gómez, E., Jordan, T.E., Allmendinger, R.W., Hegarty, K., and Kelley, S., 2005, Syntectonic Cenozoic sedimentation in the northern middle Magdalena Valley Basin of Colombia and implications for exhumation of the Northern Andes: Bulletin of the Geological Society of America, v. 117, p. 547569, doi:10.1130/B25454.1.

Gómez, E., Jordan, T.E., Allmendinger, R.W., Hegarty, K., Kelley, S., and Heizler, M., 2003, Controls on architecture of the Late Cretaceous to Cenozoic southern: GSA Bulletin, v. 115, p. 131-147, doi:10.1130/0016-7606(2003)115<0131.

Gómez, J., Nivia, Á., Montes, N.E., Diederix, H., Almanza, M.F., Alcárcel, F.A., and Madrid, C.A., 2015, 
Mapa Geológico de Colombia, in Gómez, J. and Almanza, M.F. eds., Compilando la geología de Colombia: Una visión a 2015. Servicio Geológico Colombiano. Publicaciones Geológicas Especiales No. 33., Bogotá, p. 35-60.

Graham, C.H., Parra, M., Mora, A., and Higuera, C., 2018, The Interplay between Geological History and Ecology in Mountains, in Hoorn, C., Perrigo, A., and Antonelli, A. eds., Mountains, Climate and Biodiversity, John Wiley \& Sons Ltd., p. 231-243.

Gutscher, M.A., Spakman, W., Bijwaard, H., and Engdahl, E.R., 2000, Geodynamics of flat subduction: Seismicity and tomographic constraints from the Andean margin: Tectonics, v. 19, p. 814-833, doi:10.1029/1999TC001152.

Hazzi, N.A., Moreno, J.S., Ortiz-Movliav, C., and Palacio, R.D., 2018, Biogeographic regions and events of isolation and diversification of the endemic biota of the tropical Andes: Proceedings of the National Academy of Sciences, v. 115, p. 7985-7990, doi:10.1073/pnas.1803908115.

Herd, D.G., 1975, Glacial and volcanic geology of the Ruiz-Tolima volcanic complex Cordillera Central, Colombia: Publicaciones Especiales del Ingeominas (Colombia), p. 1-48.

Hermelin, M., 2015, Landscapes and landforms of Colombia: 1-210 p., doi:10.1007/978-3-319-11800-0.

Hoorn, C. et al., 2010, Amazonia Through Time: Andean Uplift, Climate Change, Landscape Evolution, and Biodiversity: Science, v. 330, p. 927-931, doi:10.1126/science.1194585.

Horton, B.K., 2018, Tectonic Regimes of the Central and Southern Andes: Responses to Variations in Plate Coupling During Subduction: Tectonics, v. 37, p. 402-429, doi:10.1002/2017TC004624.

Horton, B.K., Anderson, V.J., Caballero, V., Saylor, J.E., Nie, J., Parra, M., and Mora, A., 2015, Application of detrital zircon U-Pb geochronology to surface and subsurface correlations of provenance, paleodrainage, and tectonics of the Middle Magdalena Valley Basin of Colombia: 
Geosphere, v. 11, p. 1790-1811, doi:10.1130/GES01251.1.

Howard, A.D., 1994, A detachment-limited model of drainage basin evolution: Water Resources Research, v. 30, p. 2261-2285, doi:10.1029/94WR00757.

Jaramillo-Villa, U., Maldonado-Ocampo, J.A., and Escobar, F., 2010, Altitudinal variation in fish assemblage diversity in streams of the central Andes of Colombia: Journal of Fish Biology, v. 76, p. 2401-2417, doi:10.1111/j.1095-8649.2010.02629.x.

Jordan, T.E., Isacks, B.L., Allmendinger, R.W., Brewer, J.A., Ramos, V.A., and Ando, C.J., 1983, Andean tectonics related to geometry of subducted Nazca plate.: Geological Society of America Bulletin, v. 94, p. 341-361, doi:10.1130/0016-7606(1983)94<341:ATRTGO>2.0.CO;2.

Karger, D.N., Conrad, O., Böhner, J., Kawohl, T., Kreft, H., Soria-Auza, R.W., Zimmermann, N.E., Linder, H.P., and Kessler, M., 2017, Climatologies at high resolution for the earth's land surface areas: Scientific Data, v. 4, p. 170122, doi:10.1038/sdata.2017.122.

Kerr, A.C., Marriner, G.F., Tarney, J., Nivia, A., Saunders, A.D., Thirlwall, M.F., and Sinton, C.W., 1997, Cretaceous Basaltic Terranes in Western Columbia: Elemental, Chronological and Sr-Nd Isotopic Constraints on Petrogenesis: Journal of Petrology, v. 38, p. 677-702, doi:10.1093/petroj/38.6.677.

Kerr, A.C., and Tarney, J., 2005, Tectonic evolution of the Caribbean and northwestern South America: The case for accretion of two Late Cretaceous oceanic plateaus: Geology, v. 33, p. 269-272, doi:10.1130/G21109.1.

Larson, P.H., Meek, N., Douglass, J., Dorn, R.I., and Seong, Y.B., 2017, How Rivers Get Across Mountains: Transverse Drainages: Annals of the American Association of Geographers, v. 107, p. 274-283, doi:10.1080/24694452.2016.1203283.

León, S. et al., 2018, Transition From Collisional to Subduction-Related Regimes: An Example From 
Neogene Panama-Nazca-South America Interactions: Tectonics, v. 37, p. 119-139, doi:10.1002/2017TC004785.

Lossada, A.C., Hoke, G.D., Giambiagi, L.B., Fitzgerald, P.G., Mescua, J.F., Suriano, J., and Aguilar, A., 2020, Detrital Thermochronology Reveals Major Middle Miocene Exhumation of the Eastern Flank ofthe Andes That Predates the PampeanFlat Slab $\left(33^{\circ}-33.5^{\circ} \mathrm{S}\right)$ : Tectonics, v. 39, p. 1-19, doi:10.1029/2019TC005764.

Luebert, F., and Weigend, M., 2014, Phylogenetic insights into Andean plant diversification: Frontiers in Ecology and Evolution, v. 2, p. 1-17, doi:10.3389/fevo.2014.00027.

Maldonado-Ocampo, J.A., Ortega-lara, A., Usma Oviedo, J.S., Galvis Vergara, G., Villa-Navarro, F.A., Vazquez Gamboa, L., Prada-Pedreros, S., and Rodríguez, C.A., 2005, Peces de los Andes de Colombia. Guía de campo: Bogotá D. C., Colombia, Instituto de Investigación de Recursos Biológicos Alexander von Humboldt.

Maldonado-Ocampo, J.A., Usma, J.S., Villa-Navarro, F.A., Ortega-Lara, A., Prada-Pedreros, S., Jiménez, L.F., Jaramillo-Villa, U., Arango, A., Rivas, T.S., and Sánchez, G.C., 2012, Peces dulceacuícolas del Chocó biogeográfico: Bogotá DC, Colombia, WWF Colombia.

Margirier, A., Robert, X., Audin, L., Gautheron, C., Bernet, M., Hall, S., and Simon-Labric, T., 2015, Slab flattening, magmatism, and surface uplift in the Cordillera Occidental (northern Peru): Geology, v. 43, p. 1031-1034, doi:10.1130/G37061.1.

Montes, C. et al., 2015, Middle Miocene closure of the Central American Seaway: Science, v. 348, p. 226229, doi:10.1126/science.aaa2815.

Montes, C., Bayona, G., Cardona, A., Buchs, D.M., Silva, C.A., Morón, S., Hoyos, N., Ramírez, D.A., Jaramillo, C.A., and Valencia, V., 2012, Arc-continent collision and orocline formation: Closing of the Central American seaway: Journal of Geophysical Research: Solid Earth, v. 117, 
doi:10.1029/2011JB008959.

Mora, A., Villagómez, D., Parra, M., Caballero, V.M., Spikings, R., Horton, B.K., Mora-Bohórquez, J.A., Ketcham, R.A., and Arias-Martínez, J.P., 2020, Late Cretaceous to Cenozoic uplift of the northern Andes: Paleogeographic implications: Servicio Geológico Colombiano, Publicaciones Geológicas Especiales 37, doi:10.32685/pub.esp.37.2019.04.

Murcia, A., and Cepeda, H., 1991a, Geología de la plancha 410 La Unión. Departamento de Nariño. Escala 1:100.000:

Murcia, A., and Cepeda, H., 1991b, Plancha 410 La Unión, Mapa Geológico de Colombia: Ingeominas,.

Murcia, A., and Pichler, H., 1986, Geoquímica y dataciones radiométricas de las ignimbritas cenozoicas del SW de Colombia: Revista CIAF, https:/pascalfrancis.inist.fr/vibad/index.php?action=getRecordDetail\&idt=8236317 (accessed January 2021).

Neuwerth, R., Suter, F., Guzman, C.A., and Gorin, G.E., 2006, Soft-sediment deformation in a tectonically active area: The Plio-Pleistocene Zarzal Formation in the Cauca Valley (Western Colombia): Sedimentary Geology, v. 186, p. 67-88, doi:10.1016/j.sedgeo.2005.10.009.

Nie, J., Horton, B.K., Saylor, J.E., Mora, A., Mange, M., Garzione, C.N., Basu, A., Moreno, C.J., Caballero, V., and Parra, M., 2012, Integrated provenance analysis of a convergent retroarc foreland system: U$\mathrm{Pb}$ ages, heavy minerals, $\mathrm{Nd}$ isotopes, and sandstone compositions of the Middle Magdalena Valley basin, northern Andes, Colombia: Earth-Science Reviews, v. 110, p. 111-126, doi:10.1016/j.earscirev.2011.11.002.

Padilla, L., and Leon, L., 1989, Aspector geológicos y geomorfológicos de como el rio Cauca corria hacia el sur: Boletín de geología, Colombia,.

Paris, G., Machette, M.N., Dart, R.L., and Haller, K.M., 2000, Map and database of Quaternary faults and 
folds in Colombia and its offshore regions: USGS Scientific Investigations Report, p. 61.

Pennington, W.D., 1981, Subduction of the Eastern Panama Basin and seismotectonics of northwestern South America: Journal of Geophysical Research: Solid Earth, v. 86, p. 10753-10770, doi:10.1029/JB086iB11p10753.

Perron, J.T., and Royden, L., 2013, An integral approach to bedrock river profile analysis: Earth Surface Processes and Landforms, v. 38, p. 570-576, doi:10.1002/esp.3302.

Poveda, G., and Mesa, O.J., 2000, On the existence of Lloró (the rainiest locality on Earth): Enhanced ocean-land-atmosphere interaction by a low-level jet: Geophysical Research Letters, v. 27, p. 16751678, doi:10.1029/1999GL006091.

Rahbek, C., Borregaard, M.K., Colwell, R.K., Dalsgaard, B., Holt, B.G., Morueta-Holme, N., NoguesBravo, D., Whittaker, R.J., and Fjeldså, J., 2019, Humboldt's enigma: What causes global patterns of mountain biodiversity? Science, v. 365, p. 1108-1113, doi:10.1126/science.aax0149.

Ramos, V.A., and Folguera, A., 2009, Andean flat-slab subduction through time: Geological Society, London, Special Publications, v. 327, p. 31-54, doi:10.1144/SP327.3.

Restrepo-Moreno, S.A., Foster, D.A., Stockli, D.F., and Parra-Sánchez, L.N., 2009, Long-term erosion and exhumation of the "Altiplano Antioqueño", Northern Andes (Colombia) from apatite (U-Th)/He thermochronology: Earth and Planetary Science Letters, v. 278, p. 1-12, doi:10.1016/j.eps1.2008.09.037.

Restrepo, J.D., and Cantera, J.R., 2013, Discharge diversion in the Patía River delta, the Colombian Pacific: Geomorphic and ecological consequences for mangrove ecosystems: Journal of South American Earth Sciences, v. 46, p. 183-198, doi:10.1016/j.jsames.2011.04.006.

Risnes, K., 1995, Géodynamique du sud-ouest des Andes colombiennes (dépression du Cauca-Patia) durant 
le Néogène: approche paléomagnétique: Université de Genève. Thèse, doi:10.13097/archiveouverte/unige: 98073 .

Royden, L., and Perron, J.T., 2013, Solutions of the stream power equation and application to the evolution of river longitudinal profiles: Journal of Geophysical Research: Earth Surface, v. 118, p. 497-518, doi:10.1002/jgrf.20031.

Saenz, E.A., 2003, Fission track thermochronology and denudational response to tectonics in the north of the Colombian Central Cordillera [Master's thesis]: Shimane University Japan.

Scherler, D., and Schwanghart, W., 2020, Drainage divide networks - Part 2: Response to perturbations: Earth Surface Dynamics, v. 8, p. 261-274, doi:10.5194/esurf-8-261-2020.

Schildgen, T.F., and Hoke, G.D., 2018, The Topographic Evolution of the Central Andes: Elements, v. 14, p. 231-236, doi:10.2138/gselements.14.4.231.

Schwanghart, W., and Scherler, D., 2014, Short Communication: TopoToolbox 2-MATLAB-based software for topographic analysis and modeling in Earth surface sciences: Earth Surf. Dynam, v. 2, p. 1-7, doi:10.5194/esurf-2-1-2014.

Siravo, G., Faccenna, C., Gérault, M., Becker, T.W., Fellin, M.G., Herman, F., and Molin, P., 2019, Slab flattening and the rise of the Eastern Cordillera, Colombia: Earth and Planetary Science Letters, v. 512, p. 100-110, doi:10.1016/j.eps1.2019.02.002.

Stokes, M.F., and Perron, J.T., 2020, Modeling the evolution of aquatic organisms in dynamic river basins: Journal of Geophysical Research: Earth Surface, p. 0-2, doi:10.1029/2020jf005652.

Suter, F., Sartori, M., Neuwerth, R., and Gorin, G., 2008, Structural imprints at the front of the ChocóPanamá indenter: Field data from the North Cauca Valley Basin, Central Colombia: Tectonophysics, v. 460, p. 134-157, doi:10.1016/j.tecto.2008.07.015. 
Thouret, J.C., Van Der Hammen, T., Salomons, B., and Juvigné, E., 1997, Late quaternary glacial stades in the Cordillera Central, Colombia, based on glacial geomorphology, tephra-soil stratigraphy, palynology, and radiocarbon dating: Journal of Quaternary Science, v. 12, p. 347-369, doi:10.1002/(sici)1099-1417(199709/10)12:5<347::aid-jqs319>3.0.co;2-\%23.

Tognelli, M.F., Lasso, C.A., Bota-sierra, C.A., Jiménez-segura, L.F., and Cox, N.A. (Eds.), 2016, Estado de Conservación y Distribución de la Biodiversidad de Agua Dulce en los Andes Tropicales: Gland, Suiza, Cambridge, UK y Arlington, USA: UICN.

Torres Hernández, M.P., 2010, Petrografía, geocronología y geoquímica de las ignimbritas de la Formación Popoyán, en el context del vulcanismo del suroccidente de Colombia [Master's thesis]: Universidad EAFIT.

Trenkamp, R., Kellogg, J.N., Freymueller, J.T., and Mora, H.P., 2002, Wide plate margin deformation, southern Central America and northwestern South America, CASA GPS observations: Journal of South American Earth Sciences, v. 15, p. 157-171, doi:10.1016/S0895-9811(02)00018-4.

Vargas, C.A., and Mann, P., 2013, Tearing and Breaking Off of Subducted Slabs as the Result of Collision of the Panama Arc-Indenter with Northwestern South America: Bulletin of the Seismological Society of America, v. 103, p. 2025-2046, doi:10.1785/0120120328.

Veloza, G., Styron, R., Taylor, M., and Mora, A., 2012, Open-source archive of active faults for northwest South America: GSA Today, v. 22, p. 4-10, doi:10.1130/GSAT-G156A.1.

Villagómez, D., and Spikings, R., 2013, Thermochronology and tectonics of the Central and Western Cordilleras of Colombia: Early Cretaceous-Tertiary evolution of the Northern Andes: Lithos, v. 160161, p. 228-249, doi:10.1016/j.lithos.2012.12.008.

Villamizar-Escalante, N., Bernet, M., Urueña-Suárez, C., Hernández-González, J.S., Terraza-Melo, R., Roncancio, J., Muñoz-Rocha, J.A., Peña-Urueña, M.L., Amaya, S., and Piraquive, A., 2021, Thermal 
history of the southern Central Cordillera and its exhumation record in the Cenozoic deposits of the Upper Magdalena Valley, Colombia: Journal of South American Earth Sciences, v. 107, p. 103105, doi:10.1016/j.jsames.2020.103105.

Wagner, L.S., Jaramillo, J.S., Ramírez-Hoyos, L.F., Monsalve, G., Cardona, A., and Becker, T.W., 2017, Transient slab flattening beneath Colombia: Geophysical Research Letters, v. 44, p. 6616-6623, doi:10.1002/2017GL073981.

Whipple, K.X., and Tucker, G.E., 1999, Dynamics of the stream-power river incision model: Implications for height limits of mountain ranges, landscape response timescales, and research needs: Journal of Geophysical Research: Solid Earth, v. 104, p. 17661-17674, doi:10.1029/1999JB900120.

Willett, S.D., McCoy, S.W., Perron, J.T., Goren, L., and Chen, C.-Y., 2014, Dynamic Reorganization of River Basins: Science, v. 343, p. 1248765-1248765, doi:10.1126/science.1248765.

Wobus, C., Whipple, K.X., Kirby, E., Snyder, N., Johnson, J., Spyropolou, K., Crosby, B., and Sheehan, D., 2006, Tectonics from topography: Procedures, promise, and pitfalls: Special Paper of the Geological Society of America, v. 398, p. 55-74, doi:10.1130/2006.2398(04). 


\section{Supplementary Materials}

This supporting information contains three figures (Figures S1 to S3) and one table (Table S1) that are cited in the main manuscript.
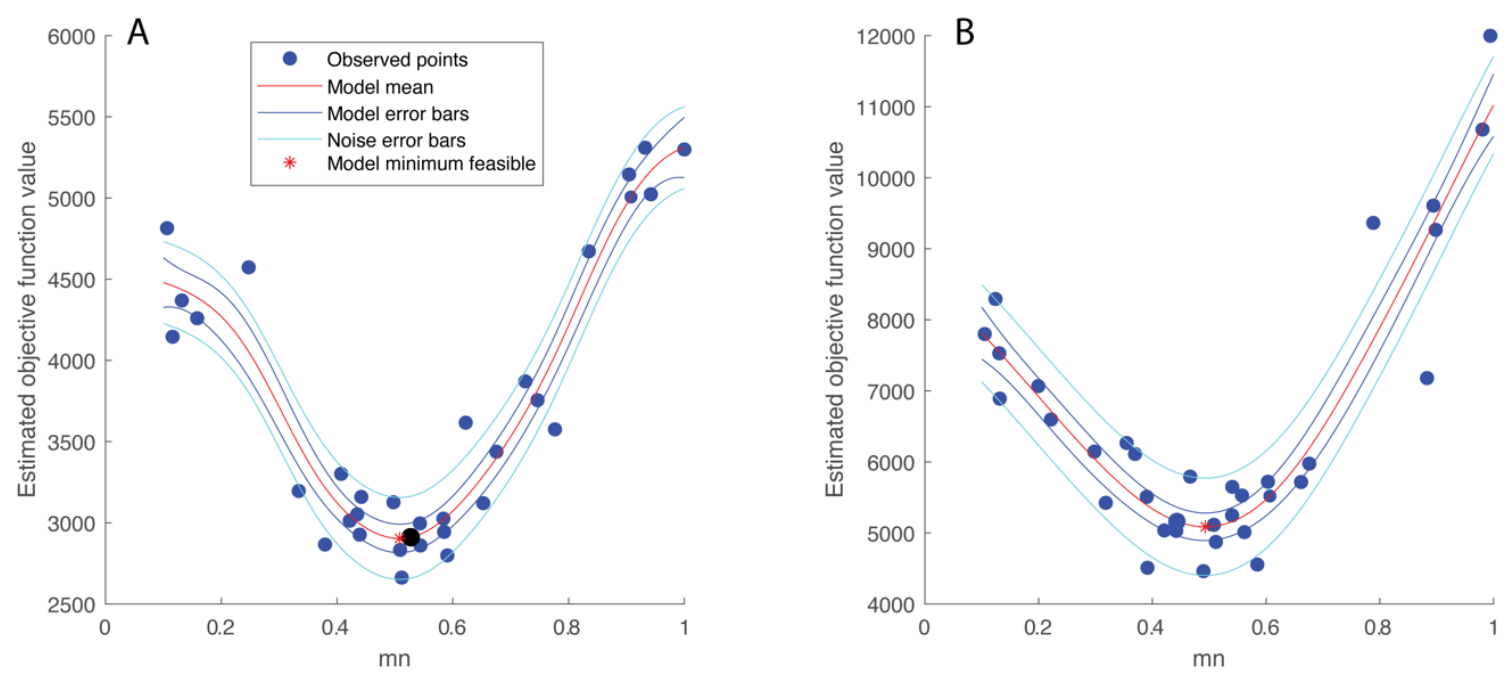

Figure S1. Estimates of best-fit concavity for the rivers of the Western Cordillera (panel A) and Central Cordillera (panel B). 

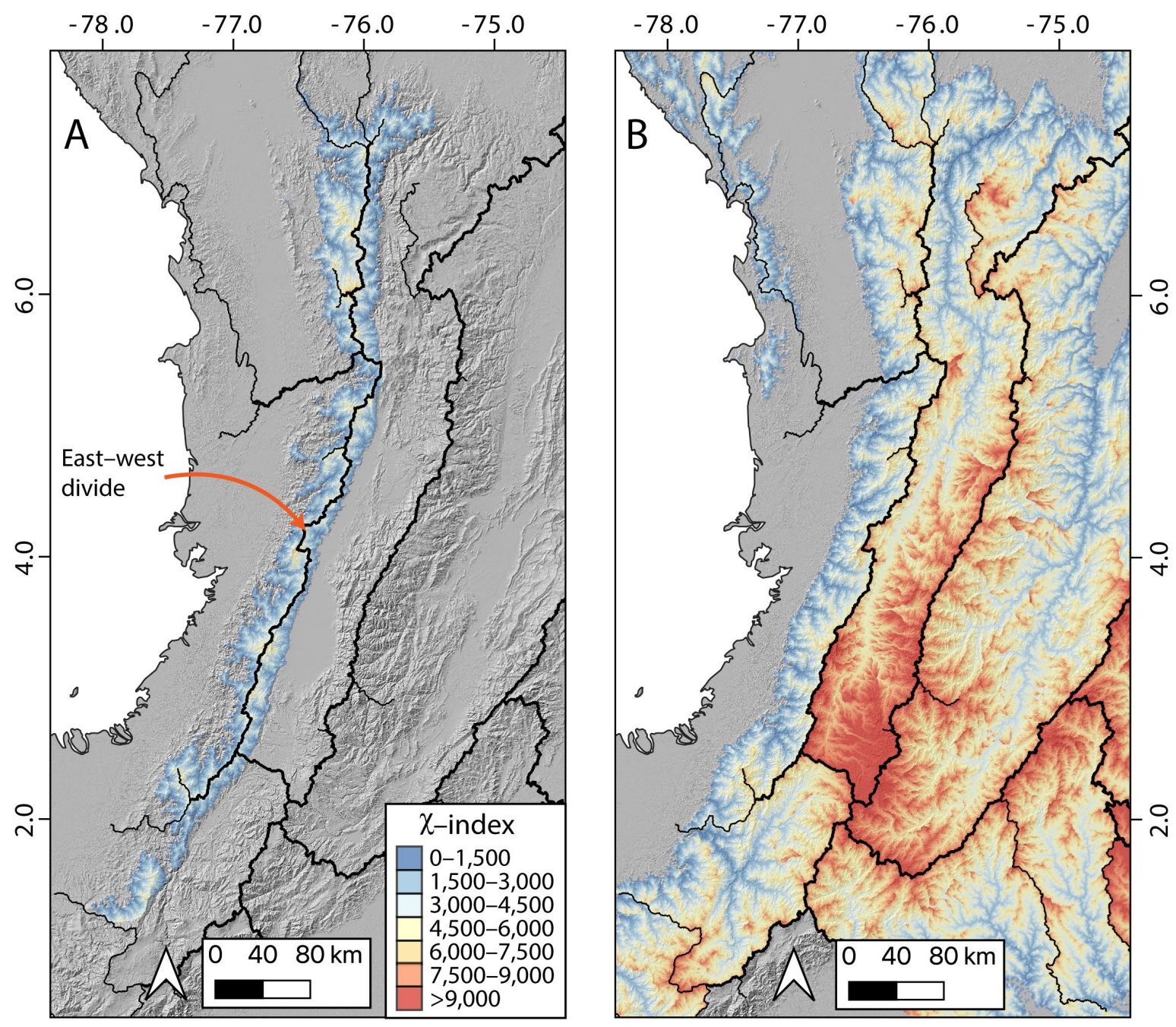

Figure S2. Effect of baselevel on $\chi$. A. $\chi$-map of the Western Cordillera using a baselevel of 950m. A. $\chi-$ map of the Northern Andes using a baselevel of $200 \mathrm{~m}$. Note that when using the $950 \mathrm{~m}$ baselevel the eastwest drainage divide across the Western Cordillera does not show any major difference in $\chi$. 


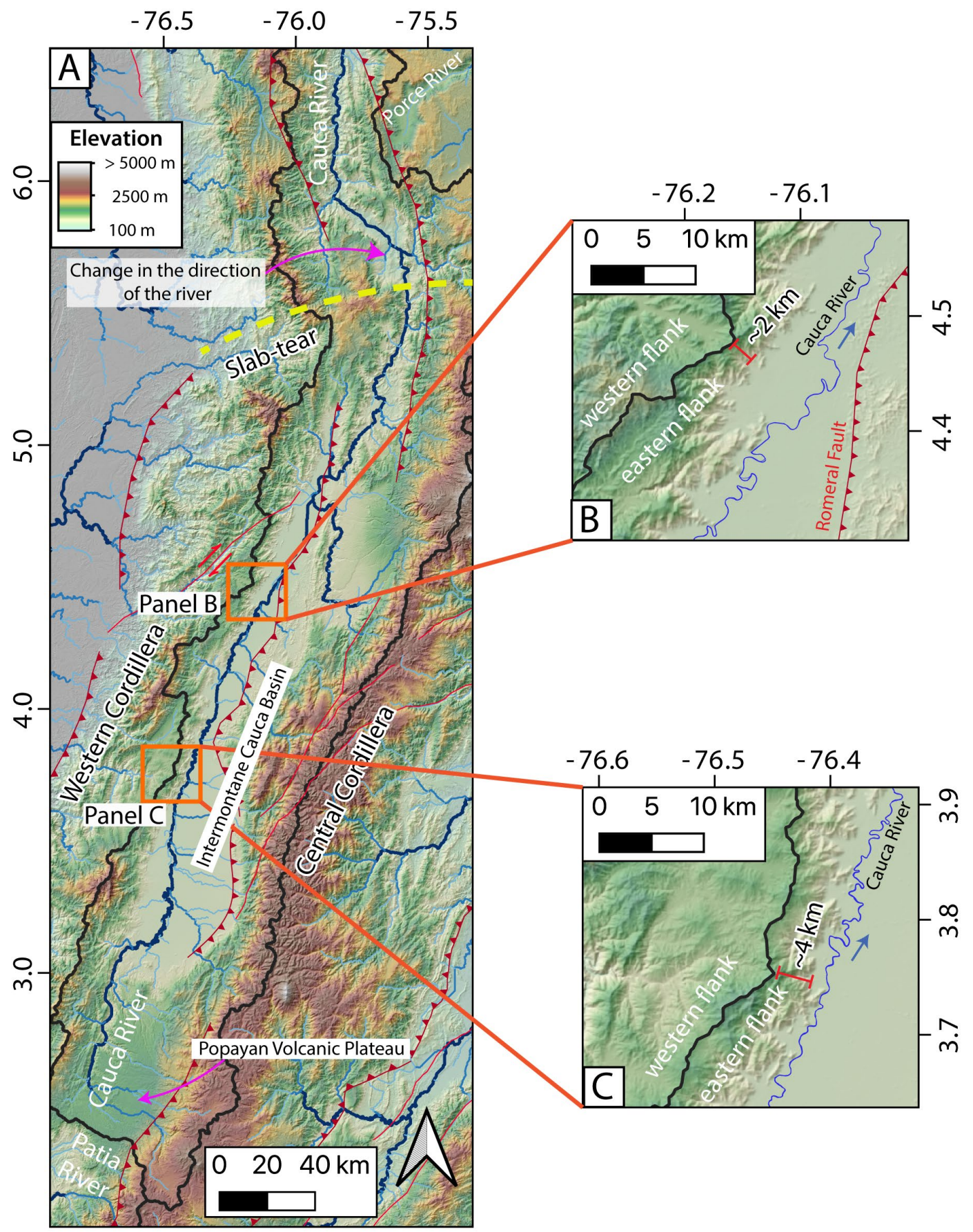

Figure S3. Close up to the topography of the Cauca Basin. Note the two locations where the distance between the east-west drainage divide and the Cauca River is $<5 \mathrm{~km}$. The proximity of the drainage divide to the Cauca River could lead to drainage capture of the upper Cauca Basin by a west draining tributary. 
Table S1. Compiled ages of the volcanic rocks in the Patia Basin.

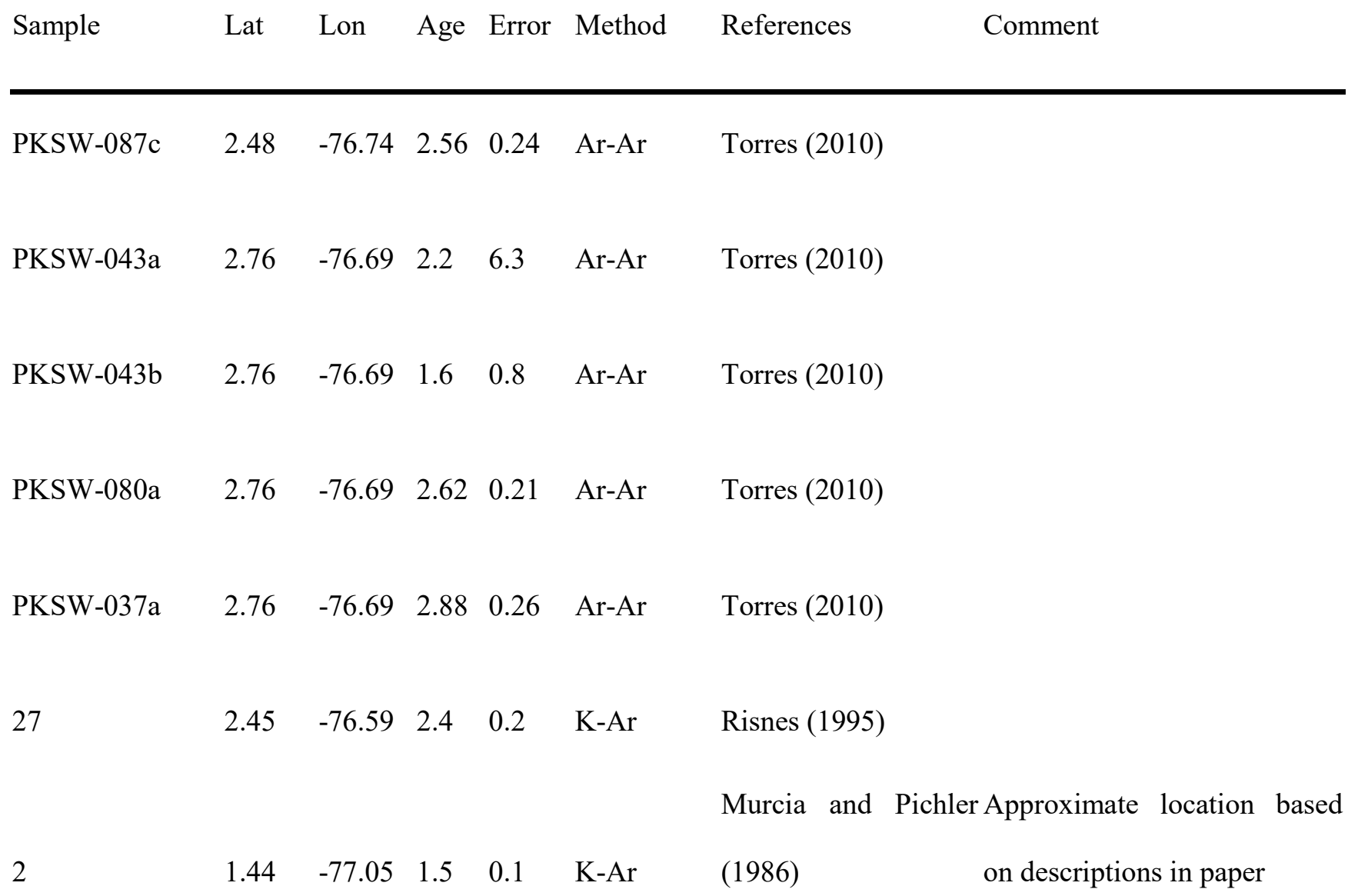

\section{References cited in the supplementary materials}

Murcia, A., Pichler, H., 1986. Geoquímica y dataciones radiométricas de las ignimbritas cenozoicas del SW de Colombia. Rev. CIAF.

Risnes, K., 1995. Géodynamique du sud-ouest des Andes colombiennes (dépression du Cauca-Patia) durant le Néogène : approche paléomagnétique. Université de Genève. Thèse. doi:10.13097/archiveouverte/unige: 98073

Torres Hernández, M.P., 2010. Petrografía, geocronología y geoquímica de las ignimbritas de la Formación Popoyán, en el context del vulcanismo del suroccidente de Colombia [Master's thesis]. Universidad EAFIT. 